\title{
Granulometric and facies analysis of Middle-Upper Jurassic rocks of Ler Dome, Kachchh, western India: an attempt to reconstruct the depositional environment
}

\author{
Asma A. Ghaznavi ${ }^{1 *}$, M.A. Quasim ${ }^{1}$, A.H.M. Ahmad ${ }^{1}$, Sumit K. Ghosh ${ }^{2}$ \\ ${ }^{1}$ Department of Geology, Aligarh Muslim University, Aligarh (UP) 202002, India \\ ${ }^{2}$ formerly Wadia Institute of Himalayan Geology, Dehradun (UK) 248001, India \\ *corresponding author, e-mail: ghaznavi.asma@gmail.com
}

\begin{abstract}
Grain size analysis is an important sedimentological tool used to unravel hydrodynamic conditions, mode of transportation and deposition of detrital sediments. For the present study, detailed grain size analysis was carried out in order to decipher the palaeodepositional environment of Middle-Upper Jurassic rocks of the Ler Dome (Kachchh, western India), which is further reinforced by facies analysis. Microtextures were identified as grooves, straight steps and V-shaped pits, curved steps and solution pits suggesting the predominance of chemical solution activity. Grain size statistical parameters (Graphic and Moment parameters) were used to document depositional processes, sedimentation mechanisms and conditions of hydrodynamic energy, as well as to discriminate between various depositional environments. The grain size parameters show that most of the sandstones are medium- to coarse-grained, moderately to well sorted, strongly fine skewed to fine skewed and mesokurtic to platykurtic in nature. The abundance of medium- to coarse-grained sandstones indicates fluctuating energy levels of the deposition medium and sediment type of the source area. The bivariate plots show that the samples are mostly grouped, except for some samples that show a scattered trend, which is either due to a mixture of two modes in equal proportion in bimodal sediments or good sorting in unimodal sediments. The linear discriminant function analysis is predominantly indicative of turbidity current deposits under shallow-marine conditions. The C-M plots indicate that the sediments formed mainly by rolling to bottom suspension and rolling condition in a beach subenvironment. Log probability curves show that the mixing between the suspension and saltation populations is related to variable energy conditions.
\end{abstract}

Key words: Grain size analysis, hydrodynamic conditions, microtextures, sedimentation, marine environment

\section{Introduction}

Grain size is an important physical property of sediments and vital for our understanding of intrinsic properties and dynamic forces that operated during deposition. Moreover, grain size parameters also help to probe the depositional environment and energy flux of diverse agents that transported the sediments. The last century witnessed remarkable work in grain size analysis as a tool for deducing provenance of sediment, transport pathways, sedimentary processes and depositional environments (Folk \& Ward, 1957; Friedman, 1961, 1967; Griffiths, 1967; Sahu, 1964, 1983; Ghosh \& Chatterjee, 1994; Tripathi \& Hota, 2013; Kanhaiya \& Singh, 2014; Ahmad et al., 2017; Kanhaiya et al., 2017). The identification of depositional environment and recognition of operative processes of sedimentation of ancient 
clastic deposits have some limitations such as diagenetic changes and subsequent modifications that framework particles undergo (Ghosh \& Chatterjee, 1994). In spite of these limitations grain size parameters have been used successfully in earlier studies in providing valuable information on provenance, transport mechanism and depositional environment (Hartmann, 2007; Weltje \& Prins, 2007; Cheetham et al., 2008; Srivastava \& Mankar, 2008). Moreover, the study of other sedimentological parameters (such as sedimentary structures and their associations, palaeocurrent, geometry, fossil content) becomes necessary in conjunction with grain size analysis for a better understanding of depositional environments, as they rely more on the processes that operated at the time of deposition of sediments (Reading, 1996).

The Kachchh Basin holds a significant place on the world map as a prospective hydrocarbon reservoir. It has attracted the attention of the international community due to the rich fossiliferous content. These levels have been widely studied for microfossils (Talib et al., 2014), biostratigraphy (Rai et al., 2015), sequence stratigraphy (Catuneanu \& Dave, 2017), provenance and tectonic setting (Ahmad \& Bhatt, 2006; Ghaznavi et al., 2015; Ghaznavi et al., 2018a, 2018b), palaeogeography (Talib \& Gaur, 2008), palaeoclimate (Khozyem et al., 2013), facies analysis (Ahmad et al., 2013), diagenesis (Ghaznavi et al., 2018c) and geochemistry (Ghaznavi et al., 2018b). However, a systematic and comprehensive textural study, combined with facies analysis in order to understand the depositional environments and processes involved during that deposition has not yet been attempted. In the present investigation an attempt is made to study the sedimentological attributes of the Dhosa Sandstone Member at Ler (Kachchh, western India) using grain size and lithofacies data. It incorporates the identification and interpretation of microtextures, basic data generation of textural parameters and statistical measures, viz., mean, median, standard deviation, skewness and kurtosis. These parameters are comprehensively described, compared and interpreted. Bivariate plots are plotted between different parameters to establish the interrelationship between them and to extract the genetic information concealed in the distribution curves. The present study is also correlated with the facies identified in the field, in order to establish the environment of deposition of these rocks.

\section{Geology of the study area}

The breakup of Gondwanaland during the Late Triassic, followed by subsequent rifting between India and Africa, led to the formation of the Kachchh Basin in western India (Biswas, 1991). The initial terrestrial sedimentation was followed by marine inundation of the Malagasy Gulf (Bajocian) and this marine condition persisted from the Middle Jurassic to the Early Cretaceous (Pandey et al., 2013). Out of total of the 3,000 $\mathrm{m}$ of the Mesozoic sediment fill, the Jurassic strata account for 700 to $>1,000 \mathrm{~m}$ thick sediment, depending on the locality (Fürsich et al., 2013). The Kachchh Basin is divided into several tilted blocks by a large fault system (Biswas, 1993). These faults existed for a long time and were reactivated during the Jurassic (Maurya et al., 2008). The joint forces of tectonic movements along the faults that influence the region even today (Maurya et al., 2008) and Deccan trap volcanism are responsible for current major landscape features and exposure of the Jurassic rocks. Traditionally, the Jurassic outcrops in the area are divided into three groups: the Island Belt amidst the northern salt marshes of the Great Rann of Kachchh, the Wagad Uplift near the eastern boundary of the basin and the Kachchh Mainland which occupies the central part of the basin.

The Kachchh Mainland exposes the best-known and undisturbed Mesozoic rocks which trend in the form of chain of domes (Alberti et al, 2013). Situated to the north of Bhuj, they extend from the Jara Dome in the west to the Habo Dome in the east with intervening Jumara, Nara (Kaiya), Keera and Jhurio domes. The study area of Ler lies to the south of the Bhuj district, with Jurassic rocks well exposed at outcrop (Fig. 1). The Callovian to Oxfordian strata in the area are assigned to the Chari Formation (Table 1). The Gypsiferous Shale Member (GSM) is dominated by bioturbated argillaceous silt containing several levels of small concretions and abundant secondary gypsum (Alberti et al., 2017). Formed below storm wave base, this unit is devoid of current-induced sedimentary structures (Alberti et al., 2013). This member coarsens into the Dhosa Sandstone Member (DSM) of fine-grained sandstone beds still containing portions of argillaceous mud and secondary gypsum from the lower member. These concretion-rich layers hold primary sedimentary structures such as trough cross-bedding and parallel lamination with high-energy levels connected with a slight fall in relative sea level. DSM is followed by the Dhosa Oolite Member (DOM). This has abundant allochthonous, ferruginous ooids that are scattered in varying abundances in the fine-grained sandstone matrix. Unlike the GSM, the DSM and DOM formed above storm wave base.

Above the DOM lies the Dhosa Conglomerate bed which has been referred to as a marker bed that is traceable throughout the Kachchh Main- 
Table 1. Lithostratigraphy of Middle-Upper Jurassic rocks in the Kachchh Basin (Fürsich et al., 1992, 2001; Pandey et al., 2009)

\begin{tabular}{|c|c|c|c|}
\hline & Age & Formation & Member \\
\hline \multirow{3}{*}{ Cretaceous } & \multirow{4}{*}{ Albian-Tithonian } & \multirow{4}{*}{ Umia } & Bhuj Member \\
\hline & & & Ukra Member \\
\hline & & & Ghuneri Member \\
\hline \multirow{4}{*}{ Late Jurassic } & & & Umia Member \\
\hline & Tithonian-Kimmeridgian & Katrol & \multirow[b]{2}{*}{ Dhosa Oolite Member } \\
\hline & \multirow[b]{2}{*}{ Oxfordian } & \multirow{7}{*}{ Chari } & \\
\hline & & & \multirow{3}{*}{ Dhosa Sandstone Member } \\
\hline \multirow{5}{*}{ Middle Jurassic } & \multirow{5}{*}{ Callovian } & & \\
\hline & & & \\
\hline & & & Gypsiferous Shale Member \\
\hline & & & Ridge Sandstone Member \\
\hline & & & Shelly Shale/Keera Golden Oolite Member \\
\hline
\end{tabular}

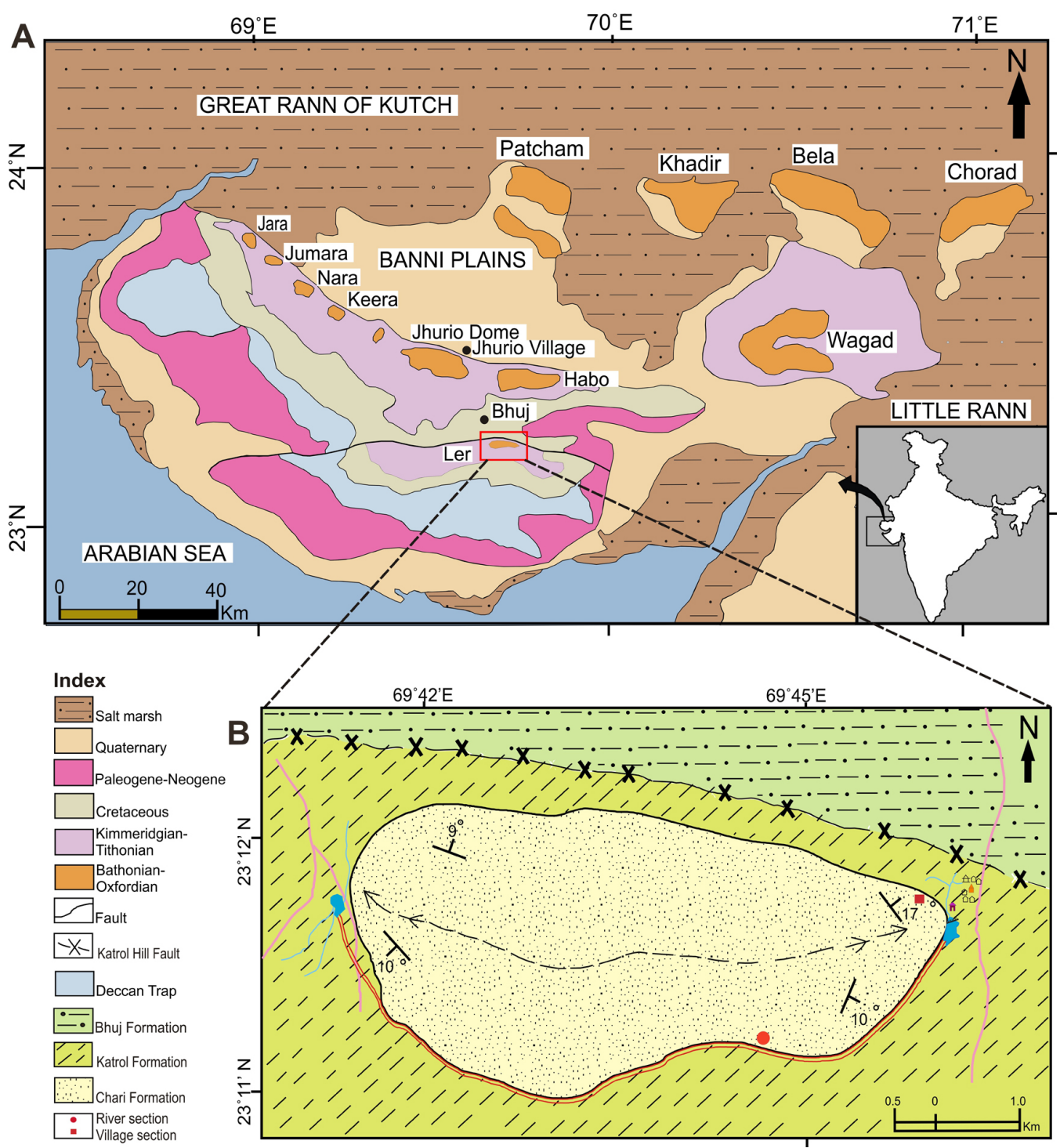

Fig. 1. A - Geological map of the Kachchh Basin (from Fürsich et al., 2001); B - Geographical extension of the Ler Dome in western India (after Ghaznavi et al., 2015) 
land (Alberti et al., 2013). This unit records strong condensation, sea level fluctuation and reworking. DCB formed under low-energy conditions below or around storm wave base (Alberti et al., 2013).

\section{Methodology}

Good exposures of the Chari Formation in the Ler Dome are developed along river and village sections (Fig. 2) which are situated in the southwest and northeast flank of the Ler Dome, respectively. The two lithologs were measured and thirty-three fresh samples of sandstones were systematically collected from the outcrop in a stratigraphical order, ideally from the Dhosa Sandstone horizon of the Chari Formation (Fig. 2) for detailed granulometric analysis. Field data were obtained through macroscale ob- servations considering physical changes along and across the successions, in combination with the nature of contacts between two successive facies. Facies were characterised, demarcated and named in the field based on their sedimentological attributes such as lithology, texture, sedimentary structures and fossils. Scanning Electron Microscope (SEM) images were used for identification of microfeatures present in the quartz grains of the Dhosa Sandstone. Thin sections of representative thirty-three samples of sandstones were selected for textural analysis. Point counting of 150-200 grains was done in each thin section following the method proposed by Chayes (1949). Phi-scale, as defined by Krumbein (1934), was used for the present study. The size data were grouped in half phi scale intervals. Plots of cumulative frequency curves were plotted on a log probability scale. From the size frequency curves, grain di-
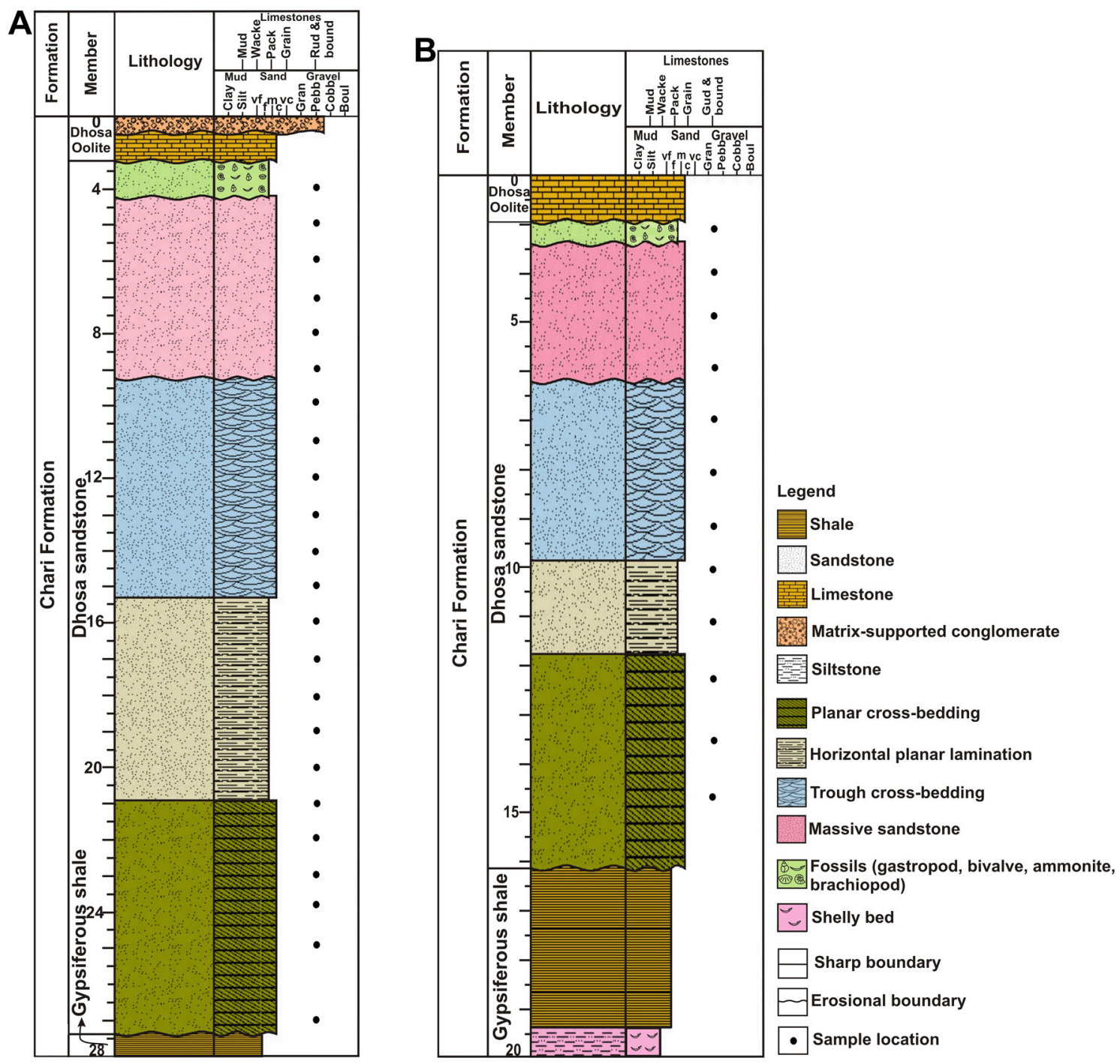

Fig. 2. Lithostratigraphical columns showing the various lithofacies of the Ler Dome, Kachchh, exposed at: A - river section (after Ghaznavi et al., 2018b); B - village section 
ameters in phi unit that are represented by $\Phi 5, \Phi 16$, Ф25, Ф50, Ф75, Ф84 and Ф95 percentiles were read. The statistical parameters for grain size distribution, such as mean size, standard deviation, skewness and kurtosis were then calculated from these values. These statistical parameters are calculated by both the graphical and moment method. The classification of statistical grain size parameters has been used in the present study according to the calculations given by Krumbein \& Pettijohn (1938), Folk (1968, 1980) and McBride (1971). The quantitative analysis of grain size data can be achieved by characterising the size with a set of numbers and further contrast and compare samples using the derived numbers. Most of the grain distributions approach a normal or Gaussian distribution when $\Phi$ size is plotted on an arithmetic scale to characterise the individual samples; conventional moment statistics can be used. This type of mathematical method of 'moments' was introduced by Krumbein \& Pettijohn (1938). Different bivariate plots are plotted between these values to establish the interrelationships.

To interpret the depositional subenvironments, the linear discriminate function (LDF) analysis was done by using following formulas:

1. To distinguish between the aeolian and beach subenvironments

$$
\begin{gathered}
\mathrm{Y}_{1 \text { Aeol:Beach }}=-3.5688 \mathrm{M}+3.7016 \mathrm{r}^{2}-2.0766 \mathrm{SK}+ \\
3.1135 \mathrm{KG}
\end{gathered}
$$

For the beach subenvironment $\mathrm{Y}$ is $>-2.7411$.

For the aeolian environment $\mathrm{Y}$ is $<-2.7411$.

2. To delineate between beach and shallow-marine subenvironment

$$
\begin{gathered}
\mathrm{Y}_{2 \text { Beach:Shallow marine }}=15.6534 \mathrm{M}+65.7091 \mathrm{r}^{2}+ \\
18.1071 \mathrm{SK}+18.5043 \mathrm{KG}
\end{gathered}
$$

For the beach subenvironment $\mathrm{Y}$ is $<63.3650$

For the shallow-marine subenvironment $\mathrm{Y}$ is $<63.3650$

3. The shallow-marine and fluvial subenvironments can be distinguished by the following equation

$$
\begin{aligned}
\mathrm{Y}_{\text {3 Shallow marine:Fluvial }}= & 0.2852 \mathrm{M}-8.7604 \mathrm{r}^{2}-4.8932 \mathrm{SK}+ \\
& 0.0428 \mathrm{KG}
\end{aligned}
$$

For the shallow-marine subenvironment $\mathrm{Y}$ is $>-7.4190$

For the fluvial environment $\mathrm{Y}$ is $<-7.4190$

4. The fluvial and marine turbidity subenvironments can be distinguished by the following equation

$$
\begin{gathered}
\mathrm{Y}_{4 \text { Fluvial:Turbidity }}=0.7215 \mathrm{M}+0.403 \mathrm{r}^{2}+6.7322 \mathrm{SK}+ \\
5.2927 \mathrm{KG}
\end{gathered}
$$

For the marine turbidity subenvironment $\mathrm{Y}$ is $>10.000$

For the fluvial environment $\mathrm{Y}$ is $<10.000$

( $\mathrm{M}=$ mean size, $\mathrm{r}=$ standard deviation, $\mathrm{SK}=$ skewness, $K G=$ kurtosis).

Energy variations and fluidity factors are dependent on different processes and the depositional environment was established by a statistical method of sediment analysis (Sahu, 1964).

\section{Results and interpretation}

\subsection{Ultra features through SEM}

Several workers, among them Krinsley \& Doornkamp (1973), Margolis \& Krinsley (1974) and Mahaney (2002), have studied quartz grain microtextures with the help of SEM. For identifying sources and genesis of various detrital sediments, surface textures of quartz grains have been used. Useful information regarding the various processes that acted on the grains during transportation and after deposition is provided by microtextures (Mahaney, 1998) and the criteria for distinguishing mechanical and chemical features and their implications have been well studied (Al-Hurban \& Gharib, 2004). Therefore, identification of provenance, processes of transport and diagenetic history of the detrital sediments can be established well by surface textural studies (Armstrong-Altrin et al., 2005; Madhavaraju et al., 2009).

SEM analysis of quartz grains from the Dhosa Sandstone revealed various surface features such as grooves, straight steps and V-shaped pits, curved steps and solution pits. Grooves are the elongated scratches and troughs with a preferred orientation (Fig. 3A). They are curved and appear in sets. The size of the grooves is variable. They are modified by the fracture or weak planes and later modified by solution activities. Quartz grains also show straight steps and V-shaped pits (Fig. 3B) along with curved and straight steps in association with silica precipitation (Fig. 3C). The most important feature that characterises quartz grains of the coastal dunes is silica precipitation. Additionally, V-shaped pits are similar to those present on the surface of quartz grains of beach sands. These features can be relicts from some subaqueous environment. They also indicate the possibility of grain transportation from a marine environ- 


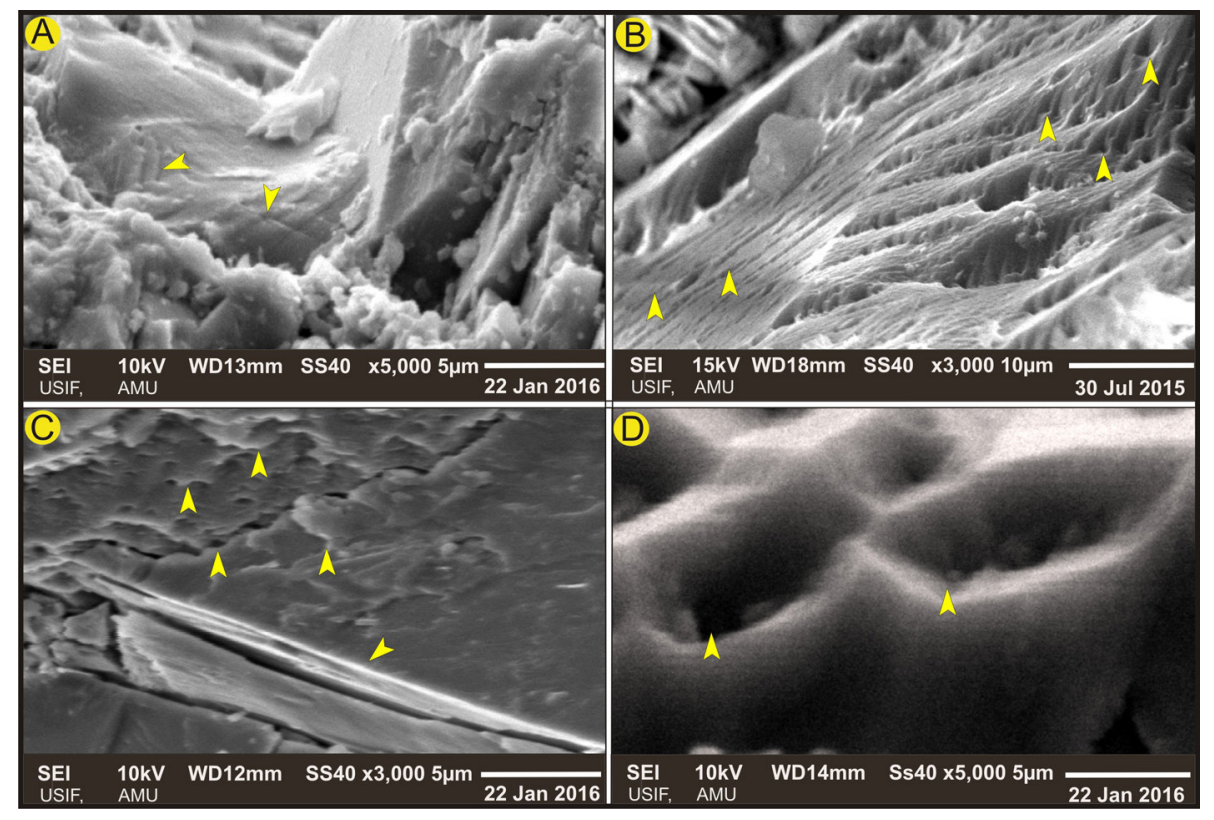

Fig. 3. Microstructures in quartz grains from Dhosa Sandstone as observed in scanning electron micrographs: A - Grooves; B - Straight steps and V-shaped pits; C - Curved and straight steps in association with silica precipitation; D - Solution pits

ment because of their proximity to the seawater. Solution pits occur mostly in form of circular or semi-circular forms having a rounded shape (Fig. 3D). Tropical, high-medium to low-energy beach zone and the chemical energy environment may be responsible for these features (Rajganapathi et al., 2013).
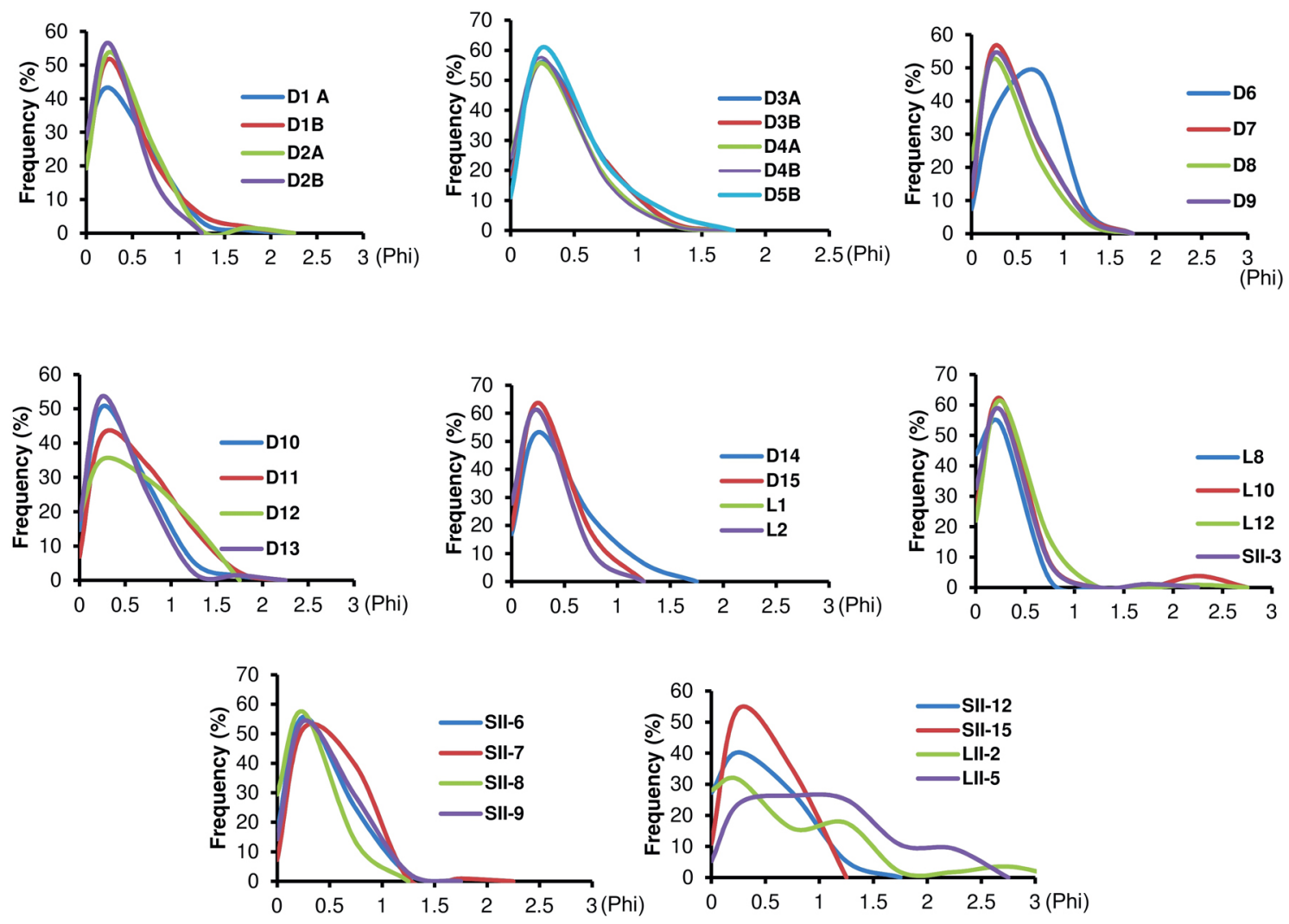

Fig. 4. Grain size distribution curves for the Dhosa sandstones
In the frequency curve, phi values are plotted against the frequency distribution of each grain size. They represent the predominance of a particular size classes or 'modality'. The curves are predominantly unimodal with a dominant peak 
around $0.5 \Phi$ (Fig. 4). However, a few of the samples also show different peaks at $1.5 \Phi$ and $2.5 \Phi$ showing bimodal nature. This can be attributed to the presence of both unimodal and bimodal populations, suggesting that sediments of both types are present, i.e., pure sand without any mixing of silt particles as well as a sand admixture with some finer particles. The unimodality indicates a consistent depositional process during which the sediments settled. The bimodality is attributed to mixing of different size populations from the source areas, variation in velocity of depositional processes, or difference in mode of transportation such as rolling, saltation or suspension. The bimodality is probably also due to low energy of the marine setting. The bimodal nature, as well as the absence of a particular trend in the Dhosa sandstones, are probably due to mixing of particles supplied or brought in by different processes or transporting agents. Alternatively, it could also be due to differences in mineral composition.

Further, phi values are plotted against the cumulative frequencies, pointing to different modes of sediment transport and deposition and their importance in the genesis of sandstone units. The curve usually shows an S-shaped trend when plotted on an arithmetic scale (Fig. 5). Sorting can be predicted by the slope of the middle portion of the curve. A broad and gentle slope indicates low kinetic energy and velocity which resulted in poor sorting. In contrast, a very steep slope is an indication of good sorting. The cumulative frequencies range from 0-100 and phi values range from 0-3.5Ф. The samples are mostly coarse grained, very few are medium grained and only one is fine grained. Hence, they can safely be assigned to the mediumto coarse-grained category. The steepness of the slope shows that these grains are very well sorted to moderately sorted.

\subsection{Statistical parameters}

\subsubsection{Statistical parameters - Graphical method}

1. Inclusive graphic median $\left(\Phi_{50}\right)$. Graphic median denotes that at particular value of $\Phi_{50}$, half of the particles are coarser, the other half finer. The values in our samples range from 0.34 to $1.16 \Phi$, averaging $0.54 \Phi$ (Table 2). This indicates that grains are generally coarse. No distinct high value is obtained from the median class, which shows that the sediments are not rich in any particular grain size.

2. Graphic mean size $(\mathrm{Mz})$. This depicts the average particle size or the central tendency of parti-
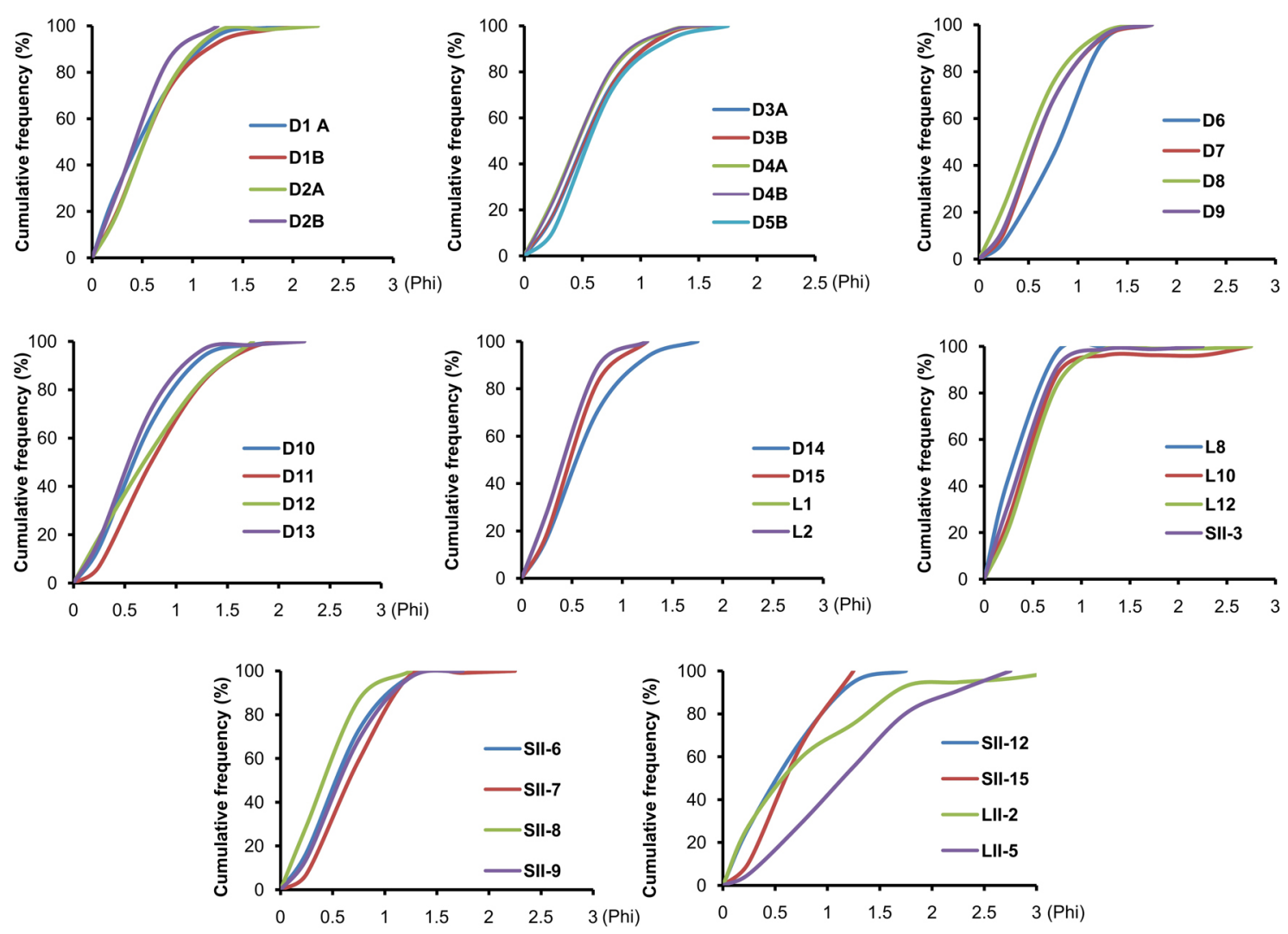

Fig. 5. Cumulative frequency curve showing trends of the Dhosa sandstones 
cles. The graphic mean ranges from 0.38 to 3.09, with an average of 1.01 (Table 2) which shows that the samples mostly belong to medium- to coarse-grained sands. Values of certain samples, such as D-4B, L2, SII-8 and SII-9, are quite high because of a predominance of a particular mode of sediment class. On the other hand, a lot of sample values, such as those of D-1A, D-2A, D-2B, etc., are low because of near-equal percentage of coarse to fine sediments (Fig. 6A). The variability in grain size is not much which makes it very well to moderately sorted type.

3. Standard deviation $\left(\sigma_{1}\right)$. This measures the sorting or uniformity of the grains indicating energy conditions that prevailed during transport and deposition. It ranges from 0.18 to $0.99 \Phi$, with an average of 0.46 (Table 2). This is an indication of the good sorting of the sediments. The majority of samples (around 18) are very well sorted, representing smooth and stable currents (Fig. 6B), followed by moderately sorted species which can be attributed to slight variability in current velocity.

4. Graphic skewness $\left(\mathrm{Sk}_{1}\right)$. This measures the degree of asymmetry in the frequency curves in terms of predominance of fine- or coarse-grained fractions. The value of skewness in our samples ranges from $-0.10 \Phi$ to $1.41 \Phi$, with an average of $0.39 \Phi$ (Table 2$)$, ranging from near symmetrical to strongly fine skewed. Most of the samples are strongly fine skewed to fine skewed and the rest are near symmetrical (Fig. 6C). The sediments show a tendency of more material in fine tail.

Table 2. Statistical parameters of grain size distribution in the Dhosa sandstones of the Chari Formation, Kachchh, calculated by the graphical method. $\Phi 50, \mathrm{Mz}, \sigma_{\mathrm{I}}$ in phi units

\begin{tabular}{|c|c|c|c|c|c|}
\hline Sample no. & Median (Ф50) & Mean size $(\mathrm{Mz})$ & Standard deviation $\left(\sigma_{\mathrm{I}}\right)$ & Skewness $\left(\mathrm{Sk}_{\mathrm{I}}\right)$ & Kurtosis $\left(\mathrm{K}_{\mathrm{G}}\right)$ \\
\hline D1(A) & 0.47 & 0.51 & 0.38 & 0.21 & 0.86 \\
\hline D1(B) & 0.52 & 1.91 & 0.92 & 0.86 & 1.13 \\
\hline D2(A) & 0.55 & 0.56 & 0.34 & 0.08 & 0.88 \\
\hline D2(B) & 0.42 & 0.45 & 0.27 & 0.21 & 0.88 \\
\hline D3(A) & 0.50 & 0.55 & 0.32 & 0.26 & 0.92 \\
\hline D3(B) & 0.40 & 1.77 & 0.90 & 0.85 & 0.88 \\
\hline $\mathrm{D} 4(\mathrm{~A})$ & 0.45 & 0.49 & 0.30 & 0.25 & 0.92 \\
\hline $\mathrm{D} 4(\mathrm{~B})$ & 0.50 & 2.46 & 0.76 & 0.85 & 0.99 \\
\hline D5(B) & 0.54 & 0.59 & 0.34 & 0.29 & 1.03 \\
\hline D6 & 0.80 & 0.77 & 0.35 & -0.10 & 0.86 \\
\hline D7 & 0.57 & 0.62 & 0.34 & 0.24 & 0.95 \\
\hline D8 & 0.48 & 1.85 & 0.99 & 0.96 & 0.98 \\
\hline D9 & 0.56 & 0.60 & 0.35 & 0.21 & 0.94 \\
\hline D10 & 0.58 & 0.63 & 0.38 & 0.19 & 0.92 \\
\hline D11 & 0.75 & 1.88 & 0.78 & 1.41 & 1.19 \\
\hline D12 & 0.71 & 0.73 & 0.47 & 0.13 & 0.79 \\
\hline D13 & 0.55 & 0.57 & 0.26 & 0.94 & 0.42 \\
\hline D14 & 0.54 & 0.58 & 0.36 & 0.25 & 0.92 \\
\hline D15 & 0.46 & 0.48 & 0.26 & 0.18 & 0.91 \\
\hline L1 & 0.44 & 0.49 & 0.29 & 0.23 & 0.74 \\
\hline L2 & 0.40 & 2.91 & 0.81 & 0.87 & 1.49 \\
\hline L8 & 0.34 & 0.40 & 0.18 & 0.50 & 0.76 \\
\hline L10 & 0.41 & 0.42 & 0.27 & 0.11 & 0.96 \\
\hline L12 & 0.45 & 0.47 & 0.28 & 0.14 & 1.00 \\
\hline SII-3 & 0.38 & 0.38 & 0.25 & 0.08 & 0.89 \\
\hline SII-6 & 0.55 & 0.56 & 0.32 & 0.12 & 0.92 \\
\hline SII-7 & 0.66 & 0.67 & 0.32 & 0.04 & 0.82 \\
\hline SII-8 & 0.40 & 2.68 & 0.76 & 0.79 & 0.95 \\
\hline SII-9 & 0.56 & 3.09 & 0.53 & 0.88 & 0.72 \\
\hline SII-12 & 0.53 & 0.58 & 0.38 & 0.23 & 0.74 \\
\hline SII-15 & 0.60 & 0.63 & 0.33 & 0.12 & 0.82 \\
\hline LII-2 & 0.56 & 0.73 & 0.60 & 0.41 & 0.74 \\
\hline LII-5 & 1.16 & 1.17 & 0.69 & 0.10 & 0.97 \\
\hline Average & 0.54 & 1.01 & 0.46 & 0.39 & 0.91 \\
\hline
\end{tabular}



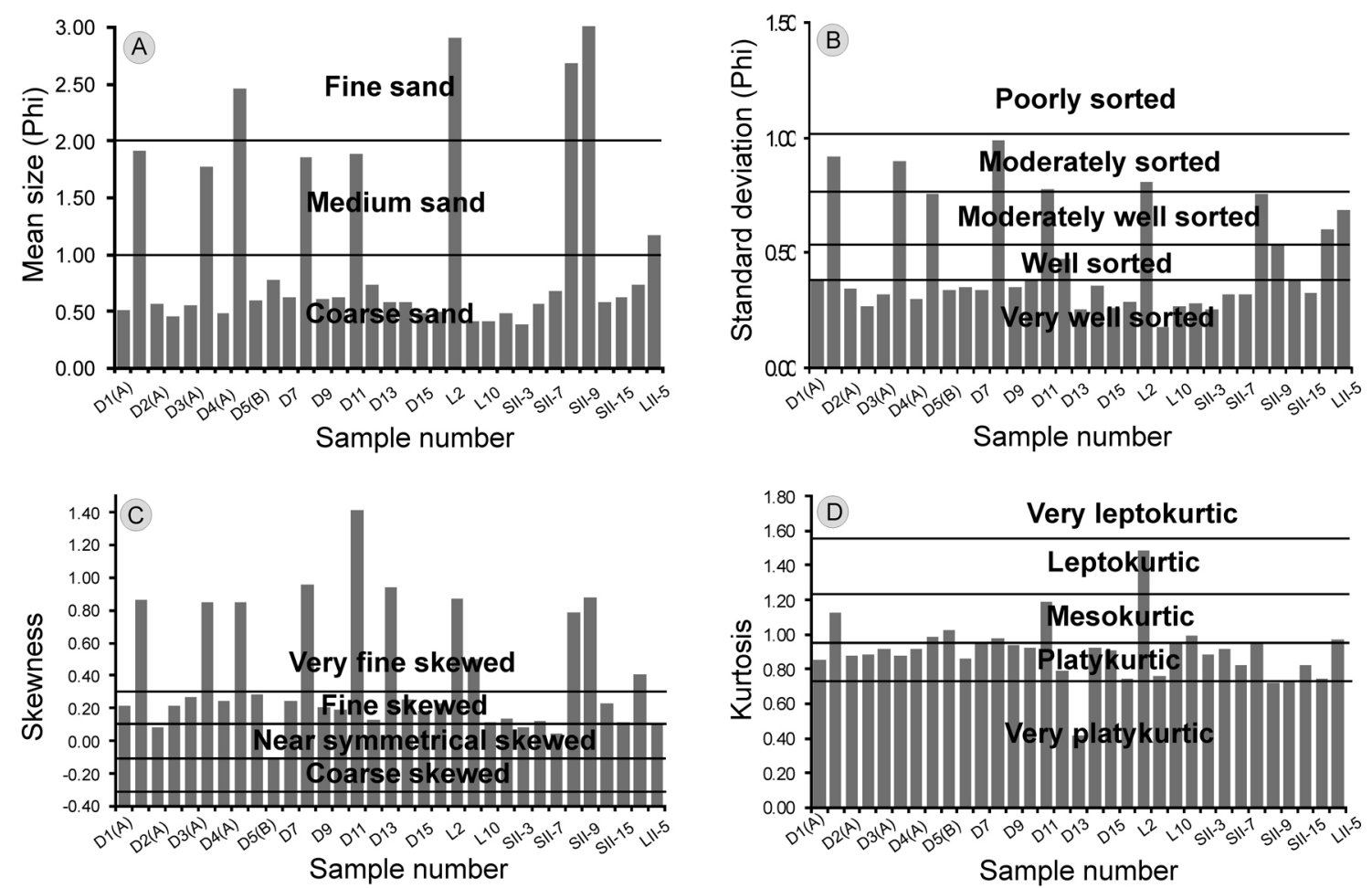

Fig. 6. Histograms of all samples plotted with respect to statistical parameters calculated by the graphical method: A Mean grain size; B - Standard deviation; C - Skewness; D - Kurtosis

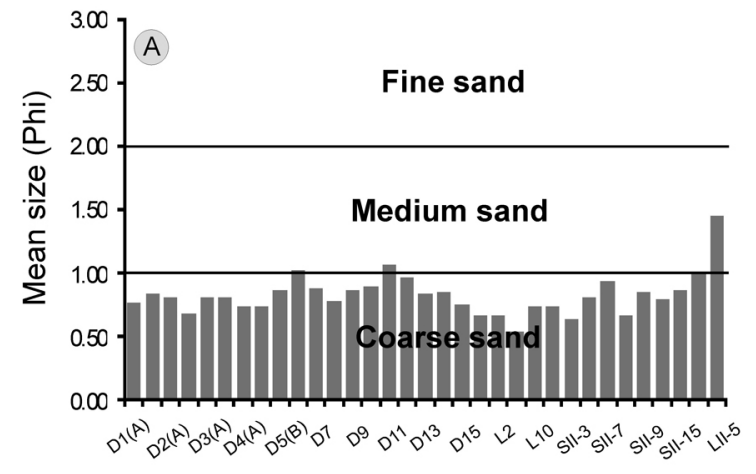

Sample number



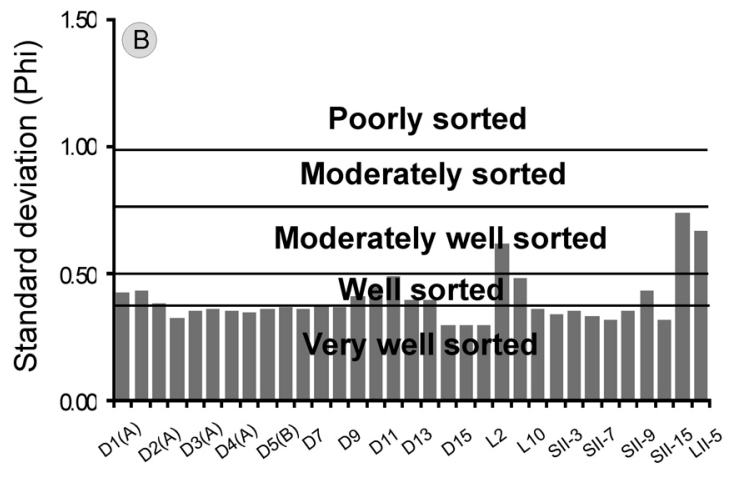

Sample number



Fig. 7. Histograms of all samples plotted with respect to statistical parameters calculated by the moment method: A Mean grain size; B - Standard deviation; C - Skewness; D - Kurtosis 
5. Graphic kurtosis $\left(\mathrm{K}_{\mathrm{G}}\right)$. The peakedness value ranges from 0.42 to 1.49 , with an average of 0.91 (Table 2). The majority of grains are mesokurtic, followed by platykurtic grains (Fig. 6D). This shows that at major instances, tails and the central portion are equally sorted. There are only three samples which are leptokurtic which has a better-sorted central portion than the tails.

\subsubsection{Statistical parameters - Moment measures method}

1. $1^{\text {st }}$ moment - Mean $(\bar{x})$. The graphic mean ranges from 0.54 to 1.45 , with an average of 0.83 (Table 3), which shows that they are of coarse size. Only four samples, D-6, D-11, LII-2 and
LII-5, are medium grained; the remainder has a coarse-grained texture (Fig. 7A).

2. $2^{\text {nd }}$ moment - Standard deviation $\left(\sigma_{\Phi}\right)$. This measures the sorting or uniformity of the grains, indicating energy conditions that prevailed during transport and deposition. It ranges from 0.30 to 0.74 , with an average of 0.40 (Table 3). Overall, the samples show good sorting of sediments (Fig. 7B).

3. $3^{\text {rd }}$ moment - Skewness $\left(\mathrm{Sk}_{\Phi}\right)$. Skewness values range from -0.24 to 2.51 , with an average of 0.49 (Table 3). The majority of samples are symmetrical followed by fine-skewed samples. Only two samples, L-10 and L-12, are very fine skewed (Fig. 7C).

Table 3. Statistical parameters of grain size distribution in the Dhosa sandstones of the Chari Formation, Kachchh, calculated by the moment method

\begin{tabular}{|c|c|c|c|c|c|c|c|c|}
\hline Sample no. & $\Sigma \mathrm{fm}$ & $\sum \mathrm{f}\left(\mathrm{m}-\overline{\mathrm{x}}_{\varphi}\right)^{2}$ & $\sum \mathrm{f}(\mathrm{m}-\overline{\mathrm{x}} \varphi)^{3}$ & $\sum \mathrm{f}(\mathrm{m}-\overline{\mathrm{x}} \varphi)^{4}$ & 1st moment & 2nd moment & 3rd moment & 4th moment \\
\hline D1(A) & 76.30 & 18.42 & 4.68 & 10.70 & 0.76 & 0.43 & 0.59 & 3.16 \\
\hline D1(B) & 83.64 & 19.03 & 6.71 & 14.04 & 0.84 & 0.44 & 0.81 & 3.88 \\
\hline D2(A) & 80.77 & 14.86 & 4.04 & 10.07 & 0.81 & 0.39 & 0.71 & 4.56 \\
\hline D2(B) & 68.53 & 10.46 & 0.44 & 2.57 & 0.69 & 0.32 & 0.13 & 2.35 \\
\hline D3(A) & 80.24 & 12.82 & 1.42 & 4.91 & 0.80 & 0.36 & 0.31 & 2.99 \\
\hline D3(B) & 80.45 & 13.13 & 1.52 & 5.11 & 0.80 & 0.36 & 0.32 & 2.97 \\
\hline D4(A) & 73.45 & 12.60 & 1.74 & 4.79 & 0.73 & 0.36 & 0.39 & 3.02 \\
\hline D4(B) & 73.33 & 12.09 & 1.70 & 4.64 & 0.73 & 0.35 & 0.41 & 3.17 \\
\hline D5(B) & 86.44 & 12.89 & 2.74 & 5.72 & 0.86 & 0.36 & 0.59 & 3.44 \\
\hline D6 & 102.78 & 13.58 & -0.96 & 5.06 & 1.03 & 0.37 & -0.19 & 2.75 \\
\hline D7 & 88.33 & 13.22 & 1.97 & 5.42 & 0.88 & 0.36 & 0.41 & 3.10 \\
\hline D8 & 77.81 & 14.25 & 2.03 & 5.81 & 0.78 & 0.38 & 0.38 & 2.86 \\
\hline D9 & 86.98 & 13.65 & 1.64 & 5.51 & 0.87 & 0.37 & 0.32 & 2.96 \\
\hline D10 & 89.00 & 17.04 & 4.07 & 10.43 & 0.89 & 0.41 & 0.58 & 3.59 \\
\hline D11 & 106.61 & 20.18 & 3.71 & 11.31 & 1.07 & 0.45 & 0.41 & 2.78 \\
\hline D12 & 96.76 & 23.79 & 1.23 & 11.43 & 0.97 & 0.49 & 0.11 & 2.02 \\
\hline D13 & 83.09 & 15.52 & 4.27 & 10.32 & 0.83 & 0.39 & 0.70 & 4.28 \\
\hline D14 & 84.74 & 15.61 & 2.65 & 7.08 & 0.85 & 0.40 & 0.43 & 2.91 \\
\hline D15 & 74.51 & 9.07 & 0.01 & 2.27 & 0.75 & 0.30 & 0.00 & 2.76 \\
\hline L1 & 66.66 & 9.04 & 0.24 & 2.13 & 0.67 & 0.30 & 0.09 & 2.61 \\
\hline L2 & 66.67 & 9.03 & 0.23 & 2.13 & 0.67 & 0.30 & 0.09 & 2.61 \\
\hline L8 & 54.38 & 37.92 & 26.45 & 23.44 & 0.54 & 0.62 & 1.13 & 1.63 \\
\hline L10 & 73.86 & 23.66 & 28.93 & 64.03 & 0.74 & 0.49 & 2.51 & 11.44 \\
\hline L12 & 73.68 & 12.92 & 6.76 & 16.73 & 0.74 & 0.36 & 1.46 & 10.02 \\
\hline SII-3 & 64.33 & 11.50 & 4.51 & 9.34 & 0.64 & 0.34 & 1.16 & 7.06 \\
\hline SII-6 & 81.15 & 12.53 & 1.05 & 4.53 & 0.81 & 0.35 & 0.24 & 2.88 \\
\hline SII-7 & 93.18 & 11.24 & 1.22 & 5.18 & 0.93 & 0.34 & 0.32 & 4.10 \\
\hline SII-8 & 66.91 & 10.01 & 0.46 & 2.42 & 0.67 & 0.32 & 0.15 & 2.41 \\
\hline SII-9 & 85.00 & 12.57 & 0.77 & 4.46 & 0.85 & 0.35 & 0.17 & 2.82 \\
\hline SII-12 & 80.19 & 18.56 & 2.29 & 7.83 & 0.80 & 0.43 & 0.29 & 2.27 \\
\hline SII-15 & 86.96 & 9.98 & -0.76 & 2.34 & 0.87 & 0.32 & -0.24 & 2.35 \\
\hline LII-2 & 101.32 & 54.48 & 45.96 & 122.81 & 1.01 & 0.74 & 1.14 & 4.14 \\
\hline LII-5 & 144.74 & 44.79 & 9.22 & 47.56 & 1.45 & 0.67 & 0.31 & 2.37 \\
\hline Average & 82.81 & 16.98 & 5.24 & 13.70 & 0.83 & 0.40 & 0.49 & 3.58 \\
\hline
\end{tabular}


4. $4^{\text {th }}$ moment - Kurtosis $\left(\mathrm{K}_{\Phi}\right)$. The value of kurtosis ranges from 1.63 to 11.44 , with an average of 3.58 . Most of the samples are mesokurtic, followed by leptokurtic and platykurtic types (Fig. 7D).

\subsection{Interrelationship of size parameters}

Bivariate plots in the form of a scatter graph between the different statistical parameters are drawn to distinguish between different depositional settings based on the assumption that they reflect differences in the fluid-flow mechanisms of sediment transportation and deposition (Sutherland \& Lee, 1994). The mean grain size and sorting plot shows
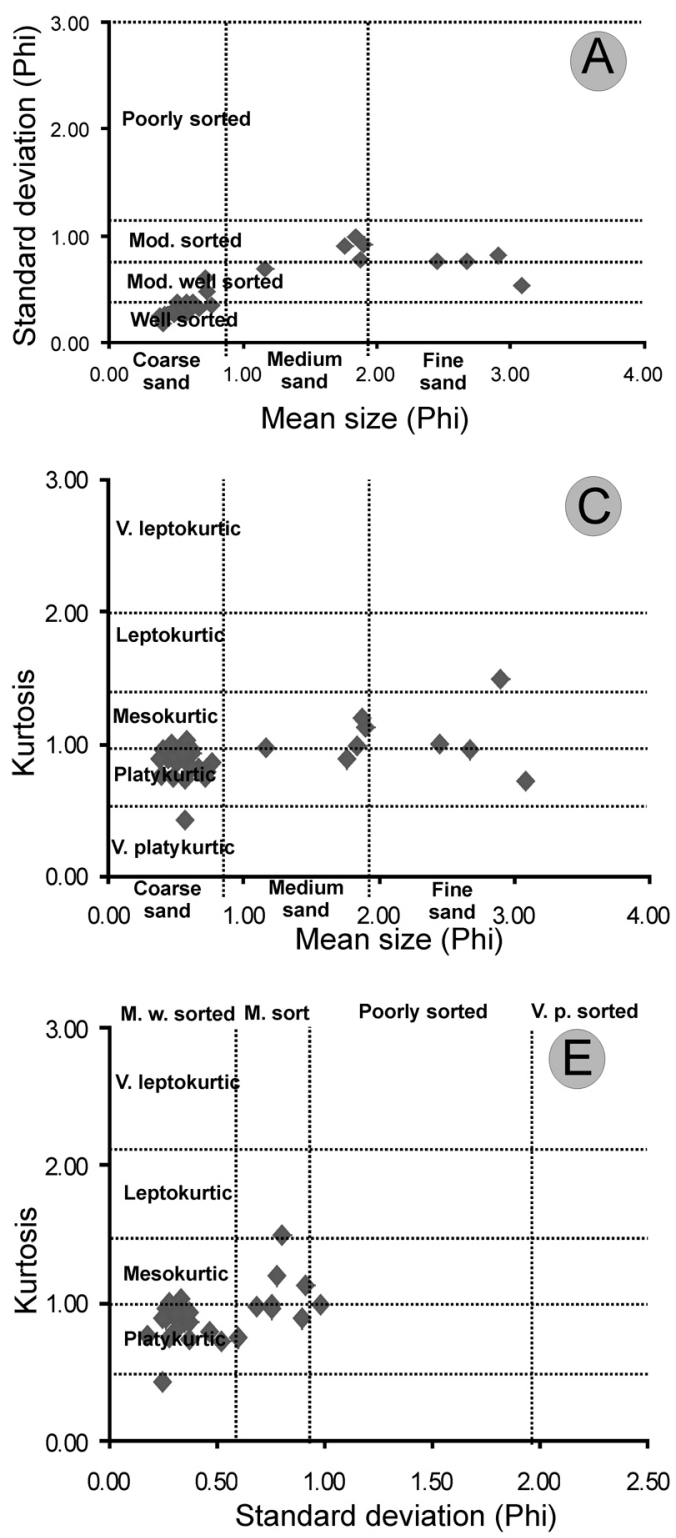

that most of the sample clusters in the field of coarse sand grains are moderately to well sorted (Fig. 8A). The action of tractive currents in the beach subenvironment can be held responsible for well-sorted sediments. The constant back and forth of grains in such a subenvironment are also responsible for the more rapid rounding of these sediments (Folk, 1980). The coarse-grained sediments indicate moderately high-energy conditions of deposition (Boggs, 2009).

The bivariate plot between mean size and skewness shows a clustering of samples around fine skewed, with average mean value of $0.5 \Phi$ (Fig. 8B). Many of them also lie in very fine-skewed category, but are confined to the medium- and fine-grain sizes. Mean size vs kurtosis bivariate shows that coars-
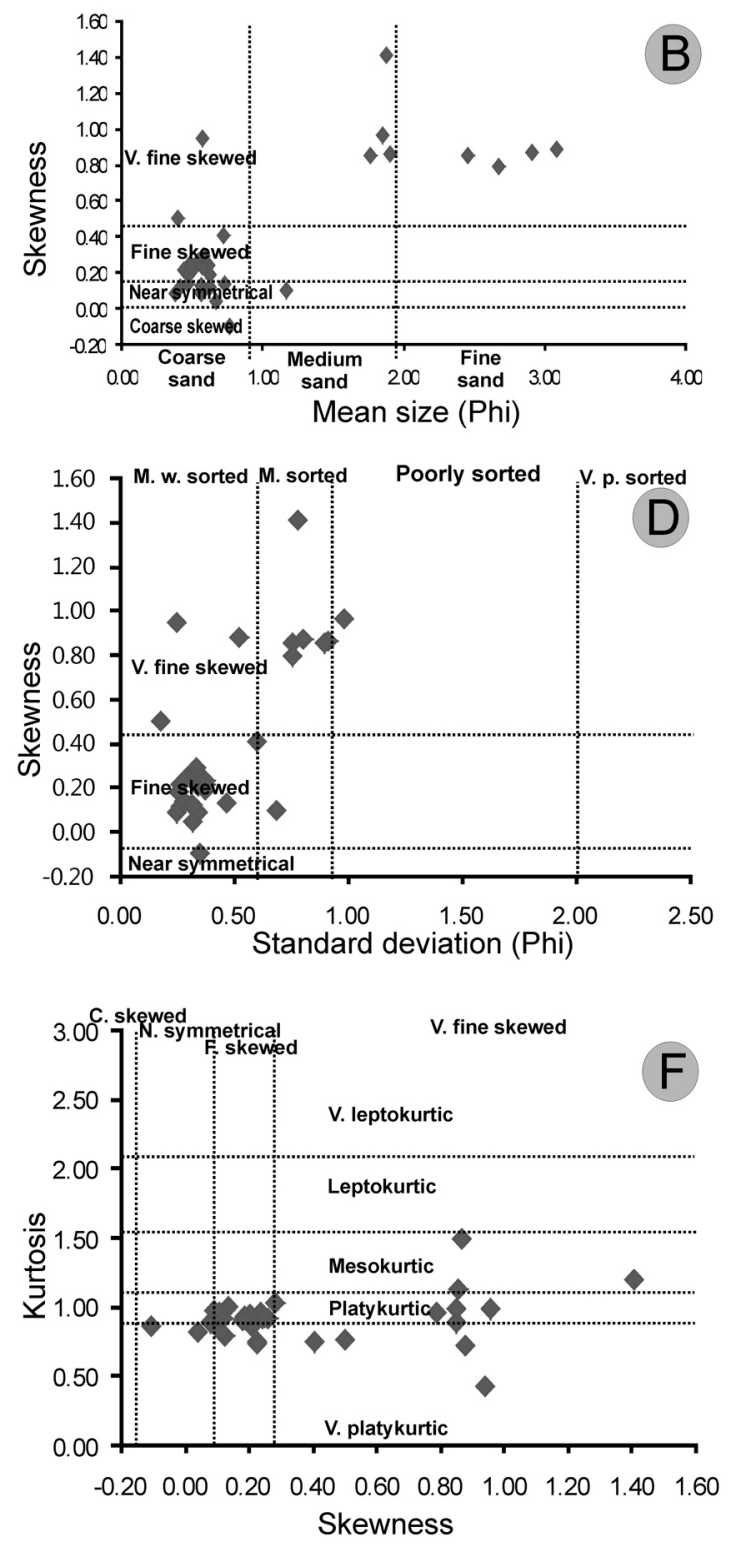

Fig. 8. Sector plot showing the bivariate relationship between: A - Grain size and sorting; B - Grain size and skewness; C - Grain size and kurtosis; D - Sorting and skewness; E - Sorting and kurtosis; F - Skewness and kurtosis 
er grains are inclined equally towards mesokurtic and platykurtic (Fig. 8C).

Standard deviation vs skewness and standard deviation vs kurtosis show that the moderately well-sorted sediments are fine skewed, having a mesokurtic to platykurtic nature (Fig. 8D, E). The skewness vs kurtosis plot shows fine- to very fineskewed, reflecting the platykurtic to very platykurtic nature of the sediments (Fig. 8F).

Further, bivariates were plotted in combination with the helical trend for the statistical parameters that were obtained by the graphical method. Mean size vs standard deviation shows clustering of the plots which suggest that the size range is smaller (Fig. 9A); this is also supported by the presence of
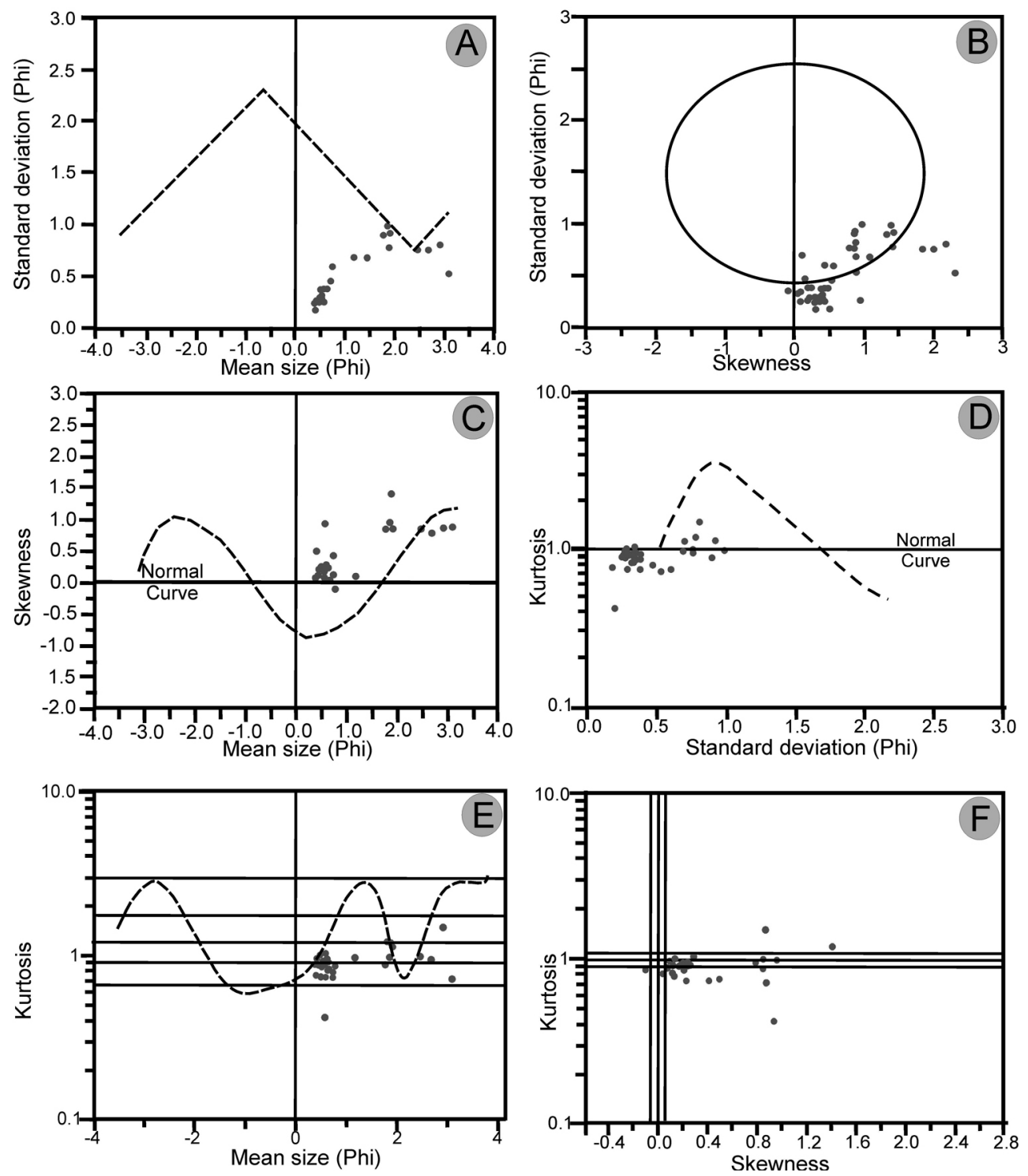

Fig. 9. Bivariate plots showing the placement of the present samples in the model plot as proposed by Folk \& Ward (1957). A - Mean grain size vs standard deviation; B - Skewness vs standard deviation; C - Mean grain size vs skewness; D - Standard deviation vs kurtosis; E - Mean grain size vs kurtosis; F - Skewness vs kurtosis 
negatively skewed one (Fig. 9C). This indicates bimodality with a predominance of sand and minor silt. Mixing of the two modes produces an overall positive skewness, which indicates that the coarser mode is more abundant.

The plot between standard deviation and kurtosis is also governed by proportions of two size modes in the mixture. Bimodal mixtures with equal amounts of the two modes have the worst sorting and lowest kurtosis (Folk \& Ward, 1957). The scatters deviate little from the pure sand region and document the presence of some fine-grained content (Fig. 9D). The majority of the grains are mesokurtic to platykurtic and moderately well sorted to well sorted. This is due to the predominance of coarse, sand-sized sediments.

The relationship between mean size and kurtosis is difficult to interpret since it shows a mixing of two or more size classes of sediments which affects the sorting of the central and tail part of the curve (Flemming, 2007; Molinaroli et al., 2009). The inverted $\mathrm{V}$ trend can be accounted for by scattering. The plot shows that the mesokurtic to platykurtic category predominates which is followed by very few leptokurtic plots in the size class of coarse to medium sand (Fig. 9E).

Skewness and kurtosis depend on the proportion of the modes present in them and follows a regular path as mean size changes (Folk \& Ward, 1957). The values of the sample studied are plotted in the shaded area which is represented by nearly pure sand and a sand-silt admixture in the plot that was established by Folk \& Ward (1957) (Fig. 9F).

\subsection{Bivariate grain size parameters}

Statistical parameters obtained by both methods (i.e., graphical and moment method) were plotted in different bivariate diagrams to confirm prevailing environmental conditions. The use of multiple bivariate helps to compare a large number of statistical parameters, which assists in working out the depositional environment precisely. In order to differentiate between river, coastal dune and beach sedimentary subenvironments, Friedman (1961) and Moiola \& Weiser (1968) plotted mean size against standard deviation. The bivariate is most effective in differentiating between beach and river sands and river and coastal dune sands and the differentiation works well regardless of whether quarter, half or whole phi data are used (Moiola \& Weiser, 1968). In the case of statistical parameters obtained by the graphical method, most of the samples cluster in the beach subenvironment with a few lying in the river and mixed environment, i.e., belonging to both river and dune subenvironments (Fig. 10A). For moment method parameters, the samples replicate the findings as they cluster in the beach subenvironment (Fig. 10A).
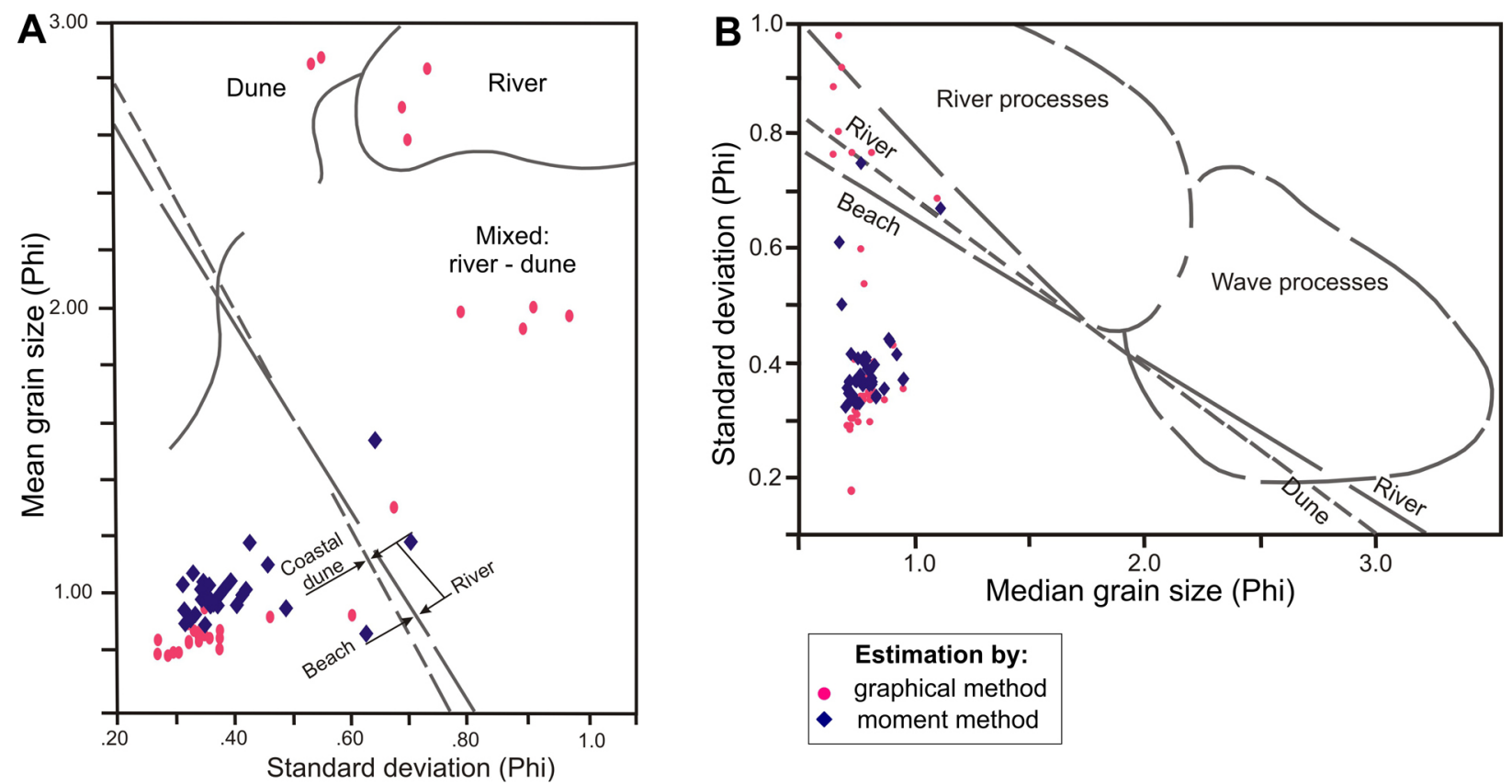

Fig. 10. A - Bivariate plot of mean grain size $v s$ inclusive graphic standard deviation (after Friedman, 1961; Moiola \& Weiser, 1968); B - Bivariate plot of inclusive graphic standard deviation vs mean grain diameter (after Stewart, 1958; Moiola \& Weiser, 1968) 

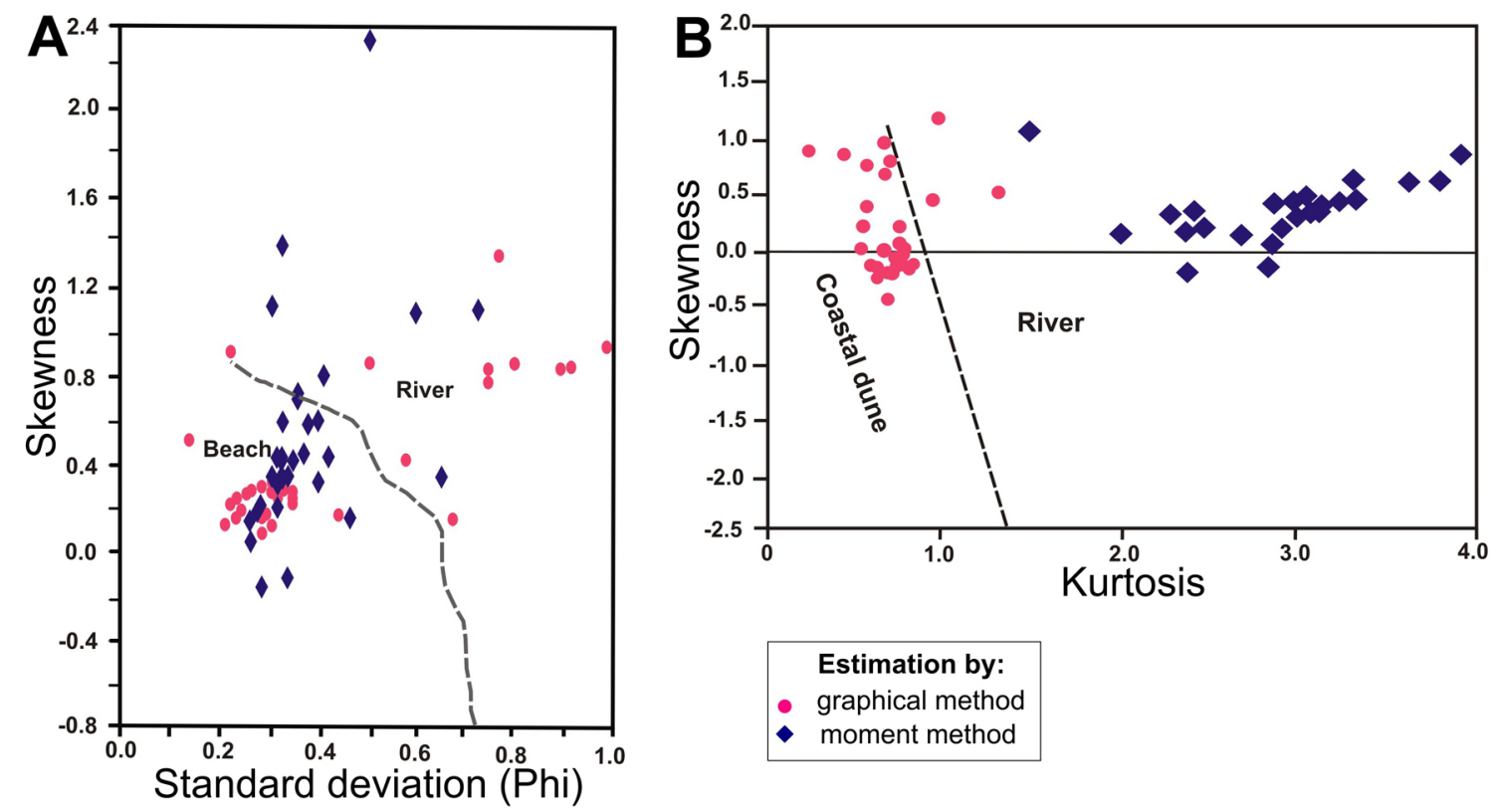

Fig. 11. A - Bivariate plot of skewness vs inclusive graphic standard deviation (after Friedman, 1967); B - Bivariate plot of skewness vs kurtosis (after Folk \& Ward, 1957)

Further, Stewart (1958) distinguished between river and wave process by plotting size vs standard deviation (Fig. 10B). For illustrative purposes, the mean size sorting boundaries of Moiola \& Weiser (1968) were redrawn. Both the plots of graphical and moment analysis depicts that sediments formed in a beach subenvironment. Another bivariate (i.e., skewness $v s$ standard deviation) to discriminate between beach and river was used

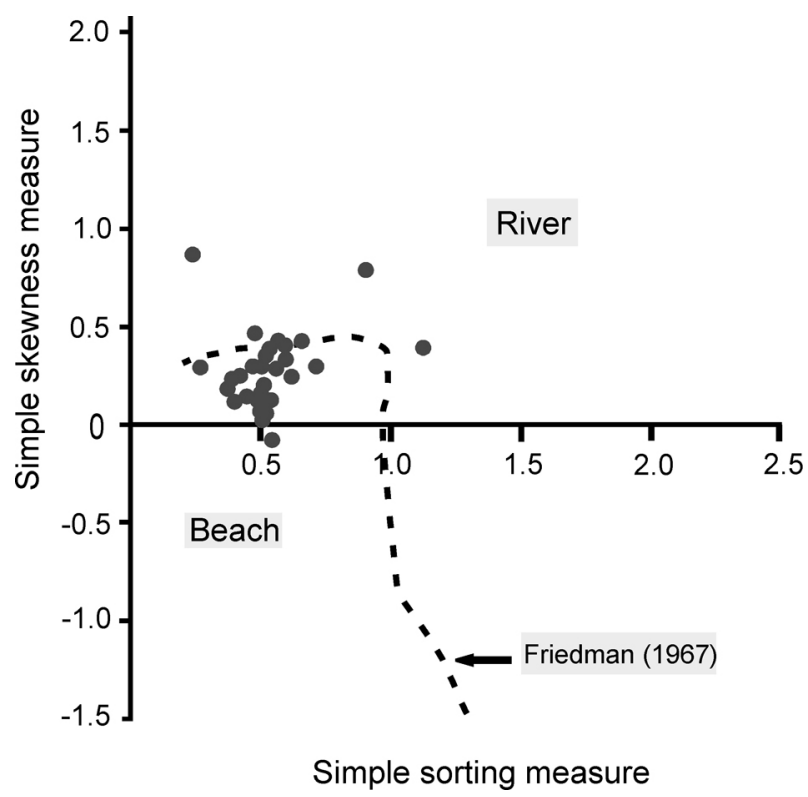

Fig. 12. Bivariate plot depicting environment of deposition simple sorting measure (SOS) vs simple skewness measure (SKS) by Friedman $(1961,1967)$. The samples show equal affinity to both beach and river environment (Fig. 11A). Folk \& Ward (1957) plotted the bivariate between kurtosis and skewness. In the case of graphical method parameters, most samples occupy the coastal dune environment, with the exception of a few samples that showed a riverine depositional environment (Fig. 11B). On the other hand, moment method statistical parameters plot exclusively in a river environment.

In order to differentiate between beach and river, a bivariate between simple sorting measures (SOS) and simple kurtosis measures (SKS) was defined by Friedman (1967) where, SOS = 1/2 (Ф95 - Ф5) and SKS $=(\Phi 95+\Phi 5)-2 \Phi 50$. The bivariate shows that most of the samples clustered in the beach subenvironment (Fig. 12).

\subsection{Linear discriminate function analysis}

Upon calculation of the linear discriminate function values by using statistical parameters obtained by the graphical method, it was found that $Y_{1}$ showed that nearly $85 \%$ of the samples belong to the beach subenvironment and only $15 \%$ fall in the aeolian environment (Table 4). $Y_{2}$ values establish that most of the sediments are of the beach type $(73 \%)$ rather than the shallow-marine one $(27 \%)$. Upon comparison of fluvial and shallow-marine predominance by using $\mathrm{Y}_{3^{\prime}}$ it is established that the latter $(78.79 \%)$ dominated over the former (21\%) (Fig. 13). $Y_{4}$ shows 


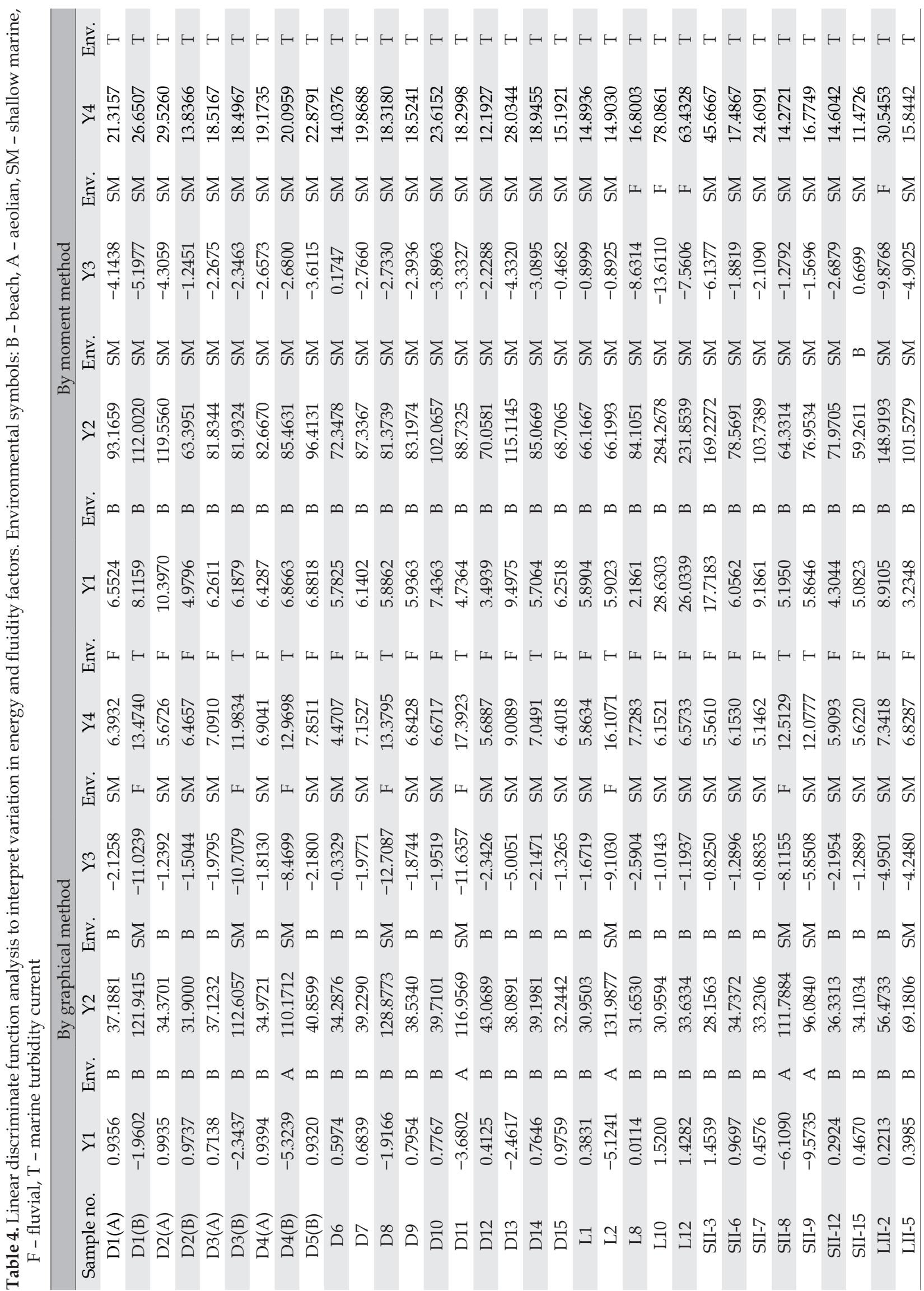




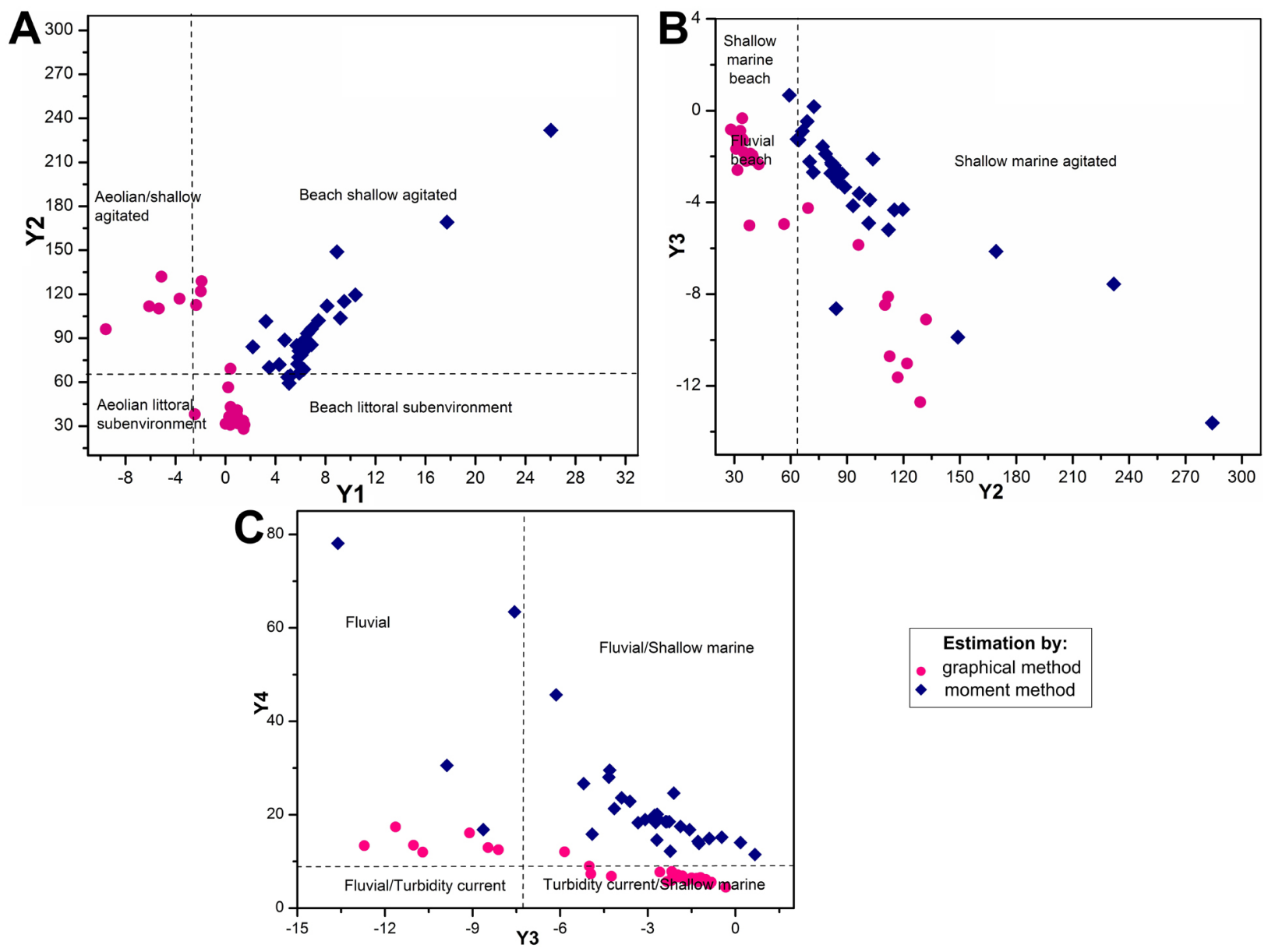

Fig. 13. Linear discriminate function plot for Dhosa sandstones. A - Y1 vs Y2 discriminates between beach and aeolian environment; B - Y2 vs Y3 discriminates between beach and shallow-marine subenvironment; C - Y3 vs Y4 discriminates between marine turbidity and fluvial environment

that amongst the turbidity and fluvial processes, the sediments were predominantly deposited by fluvial action $(73 \%)$.

When the statistical parameters calculated by moment method are used for LDF, it yields only a slight variation. $Y_{1}$ shows that all samples belong exclusively to the beach subenvironment. $Y_{2}$ shows that sediments are mostly of the shallow-marine type $(96.97 \%)$ and only few belong to the beach subenvironment $(3.03 \%)$. Further, $\mathrm{Y}_{3}$ shows that the majority of the samples are of shallow-marine type $(87.88 \%)$ and few of them are of the fluvial type $(12.12 \%)$. In case of $Y_{4^{\prime}}$ all samples show turbidity nature and none of them illustrate the fluvial type (Fig. 13).

\subsection{C-M plot}

The plot between $\mathrm{C}$ (coarse one percentile in micron) and $\mathrm{M}$ (median value in micron), obtained from phi values of the $\mathrm{C}$ and $\mathrm{M}$ from the cumulative frequen- cy curves, is plotted on the log probability curve. It helps to establish a relationship between the depositional environment and prevailing hydrodynamic conditions (Passega, 1957, 1964). In fact, the relationship between $\mathrm{C}$ and $\mathrm{M}$ is the effect of sorting by bottom turbulence (Rajganapathi et al., 2013). The $\mathrm{CM}$ pattern is divided into the following segments $\mathrm{N}-\mathrm{O}$ : rolling, OPQ: bottom suspension and rolling, QR: graded suspension, RS: uniform suspension, S: pelagic suspension. The Dhosa Sandstone samples fall in the rolling to bottom suspension and rolling condition in the beach subenvironment (Fig. 14).

\subsection{Log normal distribution curve}

To differentiate the mode of transport of sediments within a depositional medium, log probability curves, as proposed by Visher (1969), were used, which is the representation of cumulative grain size distribution on the probability (ordinate) paper. The probability scale is chosen since the distribut- 

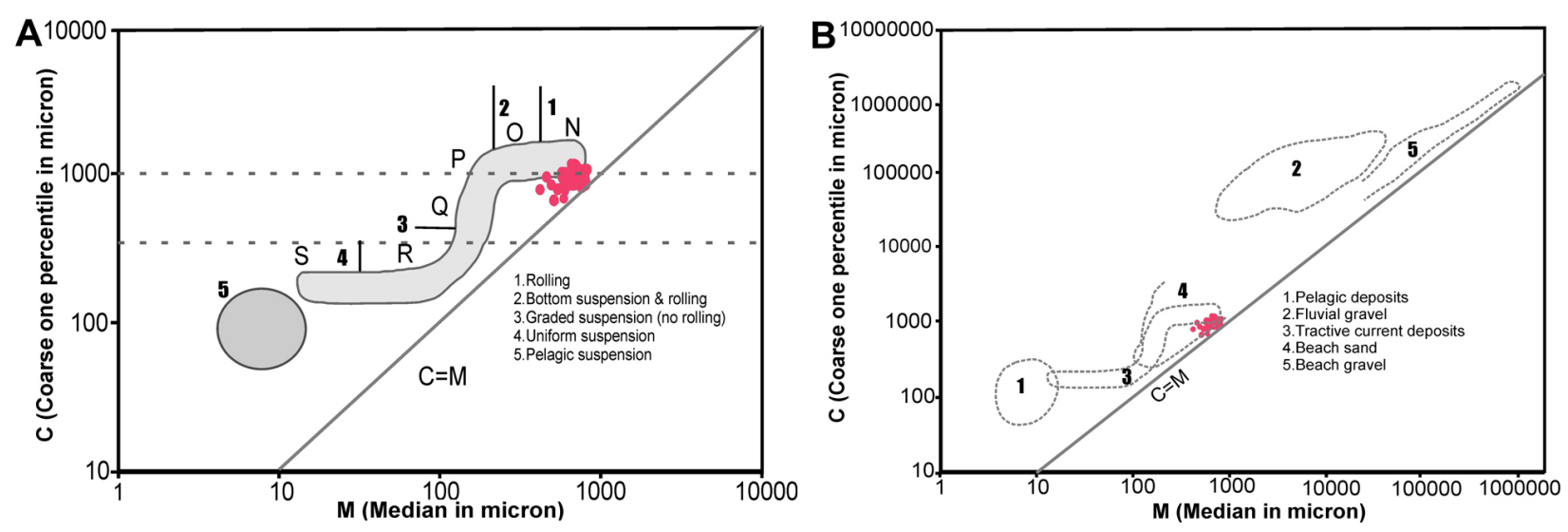

Fig. 14. CM plot to determine depositional mechanisms (A) and sedimentary subenvironments (B) of the Dhosa sandstones (after Passega, 1957, 1964)

ed data fall on a straight line. It is to be noted that these plots do not show a single straight line but two or three straight lines. Each segment depicts a different mode of transportation, namely: traction bed load (> $1.0 \mathrm{~mm})$, saltation $(0.75$ to $1.0 \mathrm{~mm})$ and suspension $(<0.1 \mathrm{~mm})$. The comparative plot of diagram (Fig. 15) shows that all the three populations, traction, saltation and suspension, are present with a predominance of the traction and saltation domains. Traction and saltation can be identified as the most frequent mode of transport. It is controlled by provenance (Visher, 1969). The grain size distribution curve also shows well-sorted population deposited by saltation. This may be attributed to the overall predominance of coarse grained sediments. Selective removal of finer materials by winnowing is a possible reason for the predominance of coarsegrained sediments.

Saltation population domains are also seen in the grain size distribution curves. The stability of the moving bed layer and rate of deposition are the factors on which this population depends. High velocity of the opposing currents and a slow rate of deposition lead to better sorting and a steeper slope in the distribution curve (Fig. 15). Suspension population domains are very few in the present population. The suspension population reflects conditions above the depositional interface (Visher, 1969). Sorting of the suspension population is ambiguous. The mix between suspension and saltation population is related to variable energy conditions.

\subsection{Sedimentary facies}

Textural parameters are useful tools in characterising the depositional environment. However, approaches such as facies analysis, can be done to verify the environment gleaned from grain size parameters.
Facies analyses of the Chari Formation rocks were carried out. Nine facies were identified (Table 5), as follows, from bottom to top: shelly bed facies (Fig. 16A) with reworked concretions (Fig. 16B), gypsiferous shale and siltstone sandstone facies (Fig. 16C), planar cross-bedded sandstone facies (Fig. 16D), laminated sandstone facies (Fig. 16F), trough cross-bedded sandstone facies (Fig. 16E), massive sandstone facies (Fig. 17A), fossiliferous facies (Fig. 17B), Dhosa Oolite facies embedded with lithoclastic-carbonates (Chiarella et al., 2017) (Fig. 17C) and matrix and clast-supported conglomerate facies (Fig. 17D). These have been further grouped into four facies associations on the basis of their common occurrence. These associations are: facies association I (tidally influenced fluvial facies association), facies association II (foreshore-offshore facies association), facies association III (onshore-offshore facies association) and facies association IV (tidal flat/lagoonal facies association). The facies association I constitutes planar and trough cross-bedded sandstone facies and matrix-supported conglomerate facies that formed in tidally influenced fluvial settings. Facies association II constitutes planar and trough cross-bedded sandstone facies, laminated sandstone facies, massive sandstone facies, fossiliferous facies and Dhosa Oolite facies. These facies were deposited in the foreshore to offshore region. Facies association III constitutes shelly bed facies deposited in the onshore-offshore region under fair weather wave and storm conditions, with long-term currents. Facies association IV constitutes gypsiferous shale and siltstone/sandstone facies that formed in a low-energy environment (Ahmad et al., 2013). Study of the lithofacies, as well as their associations, confirms that offshore basinal subenvironments are widely distributed. Sediments were derived both from fluvial as well as shallow-marine settings. However, they show a closer affinity towards the latter. 

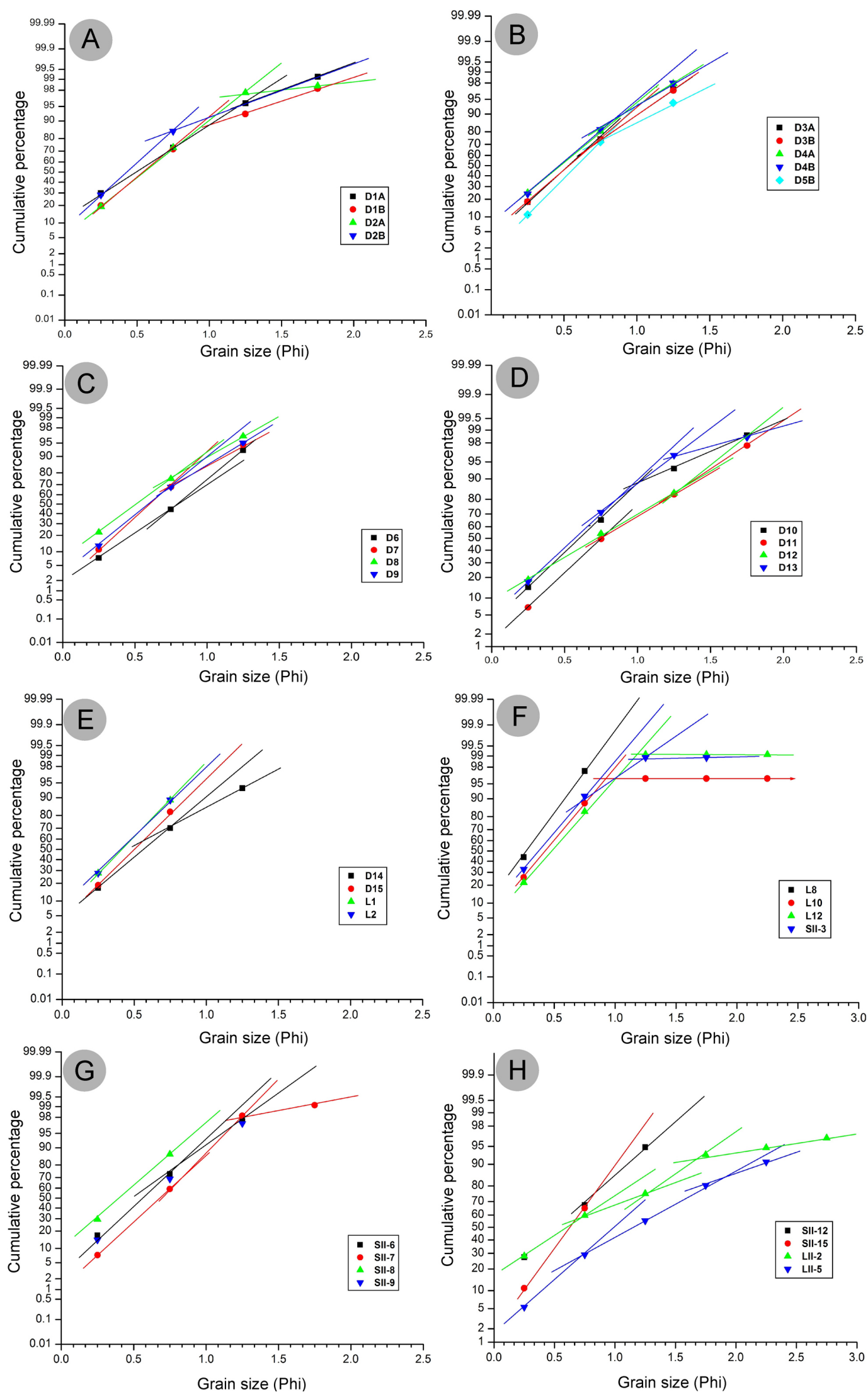

Fig. 15. Log probability curves showing the trend of traction, saltation and suspension population of all samples (after Visher, 1969) 
Table 5. Characteristics of facies, facies associations and depositional environments

\begin{tabular}{|c|c|c|c|}
\hline Facies & Characteristic features & Facies association & Depositional process/ environment \\
\hline Shelly bed facies & $\begin{array}{l}\text { Thick beds of shells (mainly } \\
\text { bivalves and brachiopods), shells } \\
\text { are unbroken as well as frag- } \\
\text { mented, disarticulated shells are } \\
\text { dominant }\end{array}$ & Facies association III & $\begin{array}{l}\text { Fair weather wave and storm condi- } \\
\text { tion with long-term currents }\end{array}$ \\
\hline $\begin{array}{l}\text { Gypsiferous shale } \\
\text { and siltstone-sand- } \\
\text { stone facies }\end{array}$ & $\begin{array}{l}\text { Light brown in color, medium- to } \\
\text { fine-grained texture dominated by } \\
\text { argillaceous silt, abundant veins } \\
\text { and sheets of gypsum of varying } \\
\text { thickness }\end{array}$ & Facies association IV & $\begin{array}{l}\text { Low-energy environment: tidal flat } \\
\text { or lagoon }\end{array}$ \\
\hline $\begin{array}{l}\text { Planar cross-bed- } \\
\text { ded sandstone } \\
\text { facies }\end{array}$ & $\begin{array}{l}\text { Reddish brown to whitish brown } \\
\text { color, medium- to coarse-grained } \\
\text { texture, moderately well sorted to } \\
\text { well sorted }\end{array}$ & $\begin{array}{l}\text { Facies associations } \\
\text { I, II }\end{array}$ & $\begin{array}{l}\text { High-energy environment: fluvial } \\
\text { channel (transverse bars) and fore- } \\
\text { shore-shoreface zone (sandy sheet } \\
\text { bars) }\end{array}$ \\
\hline $\begin{array}{l}\text { Laminated sand- } \\
\text { stone facies }\end{array}$ & $\begin{array}{l}\text { Coarse- to fine-grained sandstone, } \\
\text { sub-angular to sub-rounded } \\
\text { framework, planar stratification }\end{array}$ & Facies association II & $\begin{array}{l}\text { Heavy storms on the shoreface cause } \\
\text { offshore transport of sand and ero- } \\
\text { sion of upper part of beach }\end{array}$ \\
\hline $\begin{array}{l}\text { Trough cross-bed- } \\
\text { ded sandstone } \\
\text { facies }\end{array}$ & $\begin{array}{l}\text { Whitish to reddish brown color, } \\
\text { medium- to coarse-grained tex- } \\
\text { ture, sub-angular to sub-rounded } \\
\text { grains }\end{array}$ & $\begin{array}{l}\text { Facies associations } \\
\text { I, II }\end{array}$ & $\begin{array}{l}\text { During high water stand the } \\
\text { megaripple migration in fluvial } \\
\text { channel, deposition from longshore } \\
\text { currents in the upper shoreface }\end{array}$ \\
\hline $\begin{array}{l}\text { Massive sandstone } \\
\text { facies }\end{array}$ & $\begin{array}{l}\text { Reddish brown color, hard and } \\
\text { compact structure, medium- to } \\
\text { coarse-grained and moderately to } \\
\text { moderately well sorted texture }\end{array}$ & Facies association II & Middle shoreface \\
\hline Fossiliferous facies & $\begin{array}{l}\text { Gastropods, serpulids, bivalves } \\
\text { (mainly oysters), belemnites and } \\
\text { echinoids }\end{array}$ & Facies association II & $\begin{array}{l}\text { Shallow marine conditions domi- } \\
\text { nated with transgressive currents, } \\
\text { reworking and winnowing }\end{array}$ \\
\hline Dhosa oolite facies & $\begin{array}{l}\text { Brown and greyish color, thick } \\
\text { to thin beds, soft and friable to } \\
\text { compact fossiliferous beds }\end{array}$ & Facies association II & $\begin{array}{l}\text { Agitated offshore above storm wave } \\
\text { base }\end{array}$ \\
\hline $\begin{array}{l}\text { Matrix-supported } \\
\text { conglomerate facies }\end{array}$ & $\begin{array}{l}\text { Moderately to moderately well } \\
\text { sorted pebbles and cobles in silty } \\
\text { matrix }\end{array}$ & $\begin{array}{l}\text { Facies association } \\
\text { I }\end{array}$ & $\begin{array}{l}\text { Tidal flat and wave/storm-dominat- } \\
\text { ed shoreface }\end{array}$ \\
\hline
\end{tabular}

Shell beds that constitute the basal unit of the Ler Dome section show reworking by recurring currents which caused disarticulation. Shell beds are occasionally accompanied by reworked concretions (Fig. 16B). There is diversity in the preservation quality which indicates a time-averaged, multiple-event deposit. This suggests current-winnowed concentration (Cantalamessa et al., 2005). Gypsiferous shale and siltstone sandstone are extremely fragile, lacking any primary sedimentary feature and reflecting a protected environment setting. Veins and sheets of gypsum cutting through the beds are of a secondary diagenetic origin. The planar and trough cross bedding are high-energy features where the former shows an upright disposition and the latter a lateral migration of bed forms (Chiarella \& Longhitano, 2012; Longhitano et al., 2014). The laminated sandstones are formed by migration of low amplitude bed forms or plane beds of upper flow regime. These well-sorted, subround- ed grains are devoid of matrix, indicating a high-energy beach subenvironment. Massive sandstones that lie above the laminated ones are the products of short-lived mass flow. They are formed both by depositional (McCabe, 1977) and post-depositional processes (Allen, 1986), but in the present case there are no signs of deformation. The scattered distribution of ooids is indicative of bioturbation and their association with fine-grained siliciclastics indicates allochthonous origin transportation, probably from a nearshore place of origin (Alberti et al., 2013). Fossiliferous beds are reworked, showing the relicts of winnowing and shallow-water condition. Well-preserved and abraded shells co-occur, which indicates preservation during a large time gap, which may be due to different fluctuation rates. These can be referred to the transgressive cycles (Fürsich \& Oschmann, 1993; Fürsich, 1998). The fossiliferous beds are followed by the Dhosa oolites that are the part of DOM. They were deposited during strong trans- 

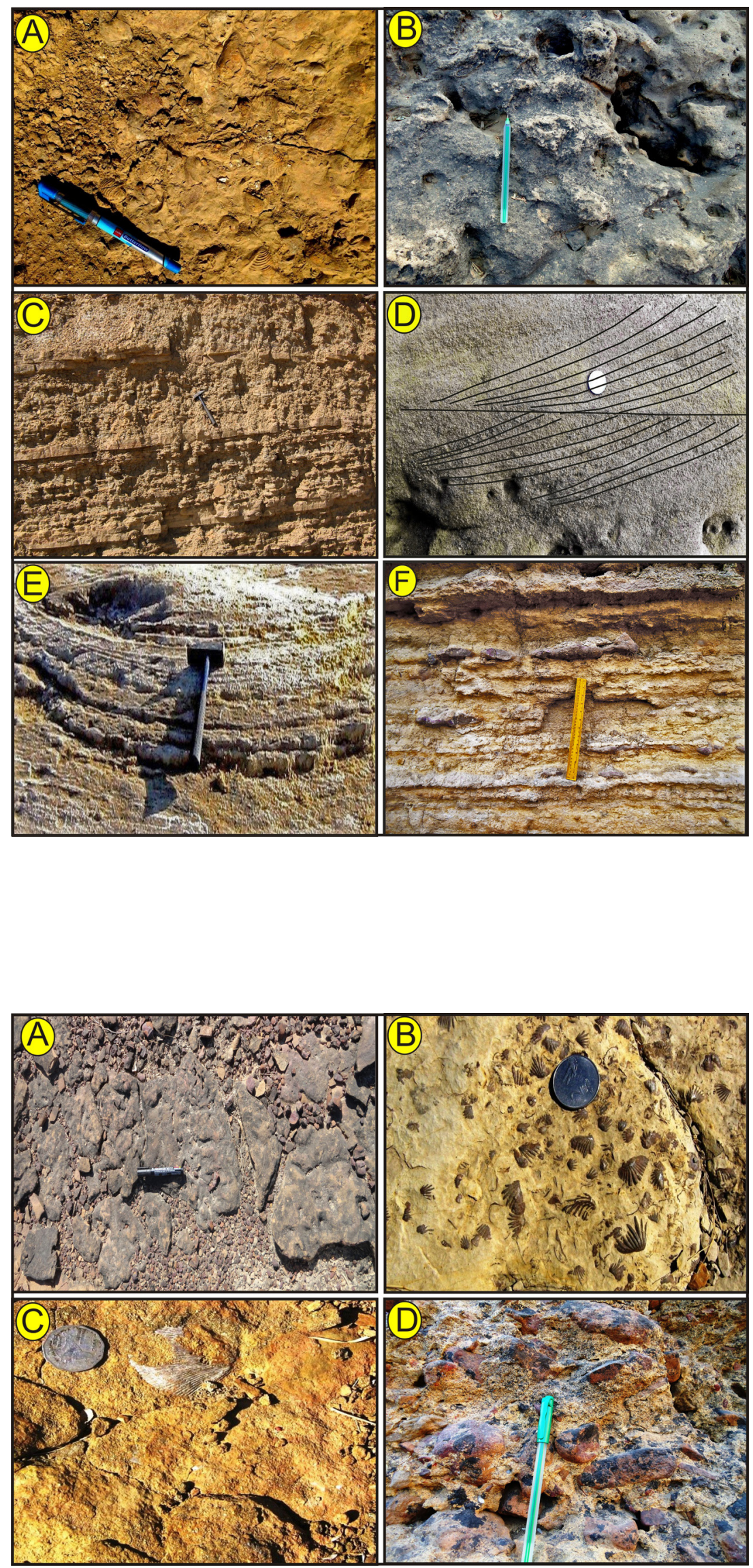

Fig. 16. A - Shell bed composed of bivalves that are disarticulated and have no preferred orientation; B - Reworked concretions with fissures and borrows; C - Light brown, thick to thin bedded fine sandstones with veins of parallel as well cross-cutting gypsum; D - Reddish brown planar cross-bedded sandstone; E Trough cross-bedded sandstone; F - Laminated sandstone with beds showing planar lamination and low-angle cross-bedding with sharp contacts
Fig. 17. A - Reddish brown, hard and compact sandstone; B - Fossiliferous bed with bivalves as major fossil biota; C - Soft and friable fossil bed of Dhosa Oolite embedded with lithoclast and bioclast, ferruginous patches are visible; D - Conglomerate bed, angular to subangular pebbles and cobbles floating in a silty matrix. These irregular and weathered surfaces have small pits and a strong ferruginous crust covering the entire unit 
gressive pulses which are evident from erosional surfaces, ferruginous crusts and a sedimentation hiatus. A matrix-supported conglomerate occurs at the top. They have a sharp erosional base with pebble imbrications and gradational clasts, which suggest deposition in subtidal channels due to gravity flows (Myrow \& Hiscott, 1991).

\section{Conclusions}

The present study reaffirms the reliability of the grain size of sandstone in interpretations of ancient depositional environments and processes, corroborated by microtextures and lithofacies analysis. The synthesis of grain size analysis data of thirty-three samples of the Dhosa Sandstone of the Ler Dome (Kachchh Basin) leads to the following conclusions:

SEM images of quartz display different microtextures such as grooves that develop predominantly by mechanical processes and straight steps and V-shaped pits, curved steps and solution pits that develop by chemical activity depicting the predominance of chemical activity over mechanical changes. A tropical environment and high-medium to low and chemical energy conditions were prevalent.

The cumulative frequency percentage curves and grain size statistics are indicative mainly of the coarse-grained nature of the sediments. In addition, most of the sandstones show a unimodal grain-size distribution.

The average sorting of all sandstones is 0.46 (moderately well sorted); they are mostly near symmetrical to strongly fine skewed in nature. Generally, the moderately well-sorted nature of the sediment could be due to a partial winnowing action, as well as to the addition or influx of previously sorted sediments in a marine environment. In most cases, both peak and tails are equally sorted, resulting in mesokurtic to platykurtic grain size patterns.

The linear discriminant functions analyses are indicative predominantly of turbidity current deposits in a shallow-marine subenvironment for the Dhosa Sandstone. The use of grain size analysis does not allow to distinguish between deep- and shallow-marine settings.

The CM pattern shows a clustered distribution of sediments in the PQ and QR segments, indicating that the sediments formed mostly by rolling to bottom suspension and rolling condition in a beach subenvironment. Log probability curves also confirm that the movements of grains were in the form of rolling to bottom suspension and surface creep (traction) population in a shallow-marine subenvironment.
Analysis of facies and their associations in space and time reveal a succession of a distinct depositional subenvironment, i.e., wave-dominated foreshore (beach) and storm wave base (offshore) both above and below storm wave base. The sediments in the study area formed during fluctuating sea levels, interrupted by storms in the shallow-marine subenvironment. In the light of results obtained by both proxies, it confirms shallow-marine conditions for deposition of the Dhosa Sandstone.

\section{Acknowledgements}

The authors are grateful to the Chairman of the Department of Geology (AMU, Aligarh) for providing the necessary facilities during the study. The corresponding author is also thankful to the University Grants Commission (U.G.C), New Delhi for the award of Senior Research Fellowship (No. F1-17.1/ 2015-16/MANF-2015-17-UTT-58619/(SA-III/ Website).

\section{References}

Ahmad, A.H.M. \& Bhat, G.M., 2006. Petrofacies, provenance and diagenesis of the Dhosa Sandstone Member (Chari Formation) at Ler, Kachchh sub-basin, western India. Journal of Asian Earth Sciences 27, 857-872.

Ahmad, A.H.M., Khan, F. \& Wasim, S.M., 2013. Facies analysis and depositional environment of the Jurassic, Jumara Dome sediments, Kachchh, western India. Journal of the Geological Society of India 82, 181-189.

Ahmad, F., Quasim, M.A., Ghaznavi, A.A., Khan, Z. \& Ahmad, A.H.M., 2017. Depositional Environment as revealed from lithofacies and grain size Measures of the Jurassic Fort Member rocks, Jaisalmer Formation, western Rajasthan. Geologica Acta 15, 153-167.

Alberti, M., Fürsich, F.T. \& Pandey, D.K., 2013. Deciphering condensed sequences: A case study from the Oxfordian (Upper Jurassic) Dhosa Oolite member of the Kachchh basin western India. Sedimentology 60, 574-598.

Alberti, M., Fürsich, F.T., Pandey, D.K. \& Mukherjee, D., 2017. Overview on the Middle to Upper Jurassic Sedimentary Succession of Gangta Bet in the Kachchh Basin, Western India, with Special Emphasis on its Lithostratigraphy, Biostratigraphy, and Palaeoenvironment. Journal Geological Society of India 89, 259-270.

Al-Hurban, A. \& Gharib, I., 2004. Geomorphological and sedimentological characteristics of coastal and inland sabkhas, Southern Kuwait. Journal of Arid Environment $58,59-85$.

Allen, J.R.L., 1986. Pedogenic calcretes in the Old Red Sandstone facies (Late Silurian-Early Carboniferous) of the Anglo-Welsh area, southern Britain. [In:] V.P. 
Wright (Eds): Paleosols: Their Recognition and Interpretation, Blackwell, Oxford, 58-86 pp.

Armstrong-Altrin, J.S., Madhavaraju, J., Ramasamy, S. \& Gladwin Gnana Asir, N., 2005. Provenance and depositional history of sandstones from the Upper Miocene Kudankulam Formation, Tamil Nadu. Journal of the Geological Society of India 66, 59-65.

Biswas, S.K., 1991. Stratigraphy and sedimentary evolution of the Mesozoic basin of Kutch, western India. [In:] S.K., Tandon, C.C., Pant \& S.M., Casshyap (Eds): Stratigraphy and sedimentary evolution of western India, Gyanodaya Prakashan, Nainital, 74-103 pp.

Biswas, S.K., 1993. Geology of Kutch. KD Malaviya Institute of Petroleum Exploration, Dehradun, 450 pp.

Boggs, S.Jr., 2009. Petrology of Sedimentary Rocks, Second Edition, Cambridge University Press, New York, 67$98 \mathrm{pp}$.

Cantalamessa, G., Di Celma, C. \& Ragaini, L., 2005. Sequence stratigraphy of the Punta Ballena Member of the Jama Formation (Early Pleistocene, Equador): insights from integrated sedimentologic, taphonomic and paleoecologic analysis of molluscan shell concentrations. Palaeogeography, Palaeoclimatology, Palaeoecology 216, 1-25.

Catuneanu, O. \& Dave, A., 2017. Cenozoic sequence stratigraphy of the Kachchh Basin, India. Marine and Petroleum Geology 86, 1106-1132.

Chayes, F., 1949. A simple Point Counter for thin section analysis. American Mineralogist 34, 1-11.

Cheetham, M.D., Keene, A.F., Bush, R.T., Sullivan, L.A. \& Erskine, W.D., 2008. A comparison of grain-size analysis methods for sand-dominated fluvial sediments. Sedimentology 55, 1905-1913.

Chiarella, D. \& Longhitano, S.G., 2012. Distinguishing depositional environments in shallow water mixed, bio-siliciclastic deposits on the base of the degree of heterolithic segregation (Gelasian, southern Italy). Journal of Sedimentary Research 82, 969-990.

Chiarella, D., Longhitano, S.G. \& Tropeano, M., 2017. Types of mixing and heterogeneities in siliciclastic-carbonate sediments. Marine and Petroleum Geology 88, 617-627.

Flemming, B.W., 2007. The influence of grain-size analysis methods and sediment mixing on curve shapes and textural parameters: implications for sediment trend analysis. Sedimentary Geology 202, 425-435.

Folk, R.L., 1968. Bimodal supermature sandstones: product of the desert floor. [In:] Proceedings of the 23rd International Geological Congress, Prague, 8, 9-32.

Folk, R.L., 1980. Petrology of Sedimentary Rocks. Hemphill, Austin, 182 pp.

Folk, R.L. \& Ward, M.C., 1957. Brazos River bars: a study in the significance of grain size parameters. Journal of Sedimentary Research 27, 3-27.

Friedman, G.M., 1961. Distinction between dune, beach and river sands from their textural characteristics. Journal of Sedimentary Research 31, 514-529.

Friedman, G.M., 1967. Dynamic processes and statistical parameters compared for size frequency distribution of beach river sands. Journal of Sedimentary Research 37, 327-354.
Fürsich, F.T., 1998. Environmental distribution of trace fossils in the Jurassic of Kachchh (Western India). Facies 39, 243-272.

Fürsich, F.T. \& Oschmann, W., 1993. Shell beds as tools in basin analysis: the Jurassic of Kachchh, western India. Journal of the Geological Society, London 150, 169-185.

Fürsich, F.T., Alberti, M. \& Pandey, D. K., 2013. Stratigraphy and palaeoenvironments of the Jurassic rocks of Kachchh. Field Guide. Beringeria, Special Issue 7, 1-174.

Fürsich, F.T., Oschmann, W., Singh, I.B. \& Jaitly, A.K., 1992. Hardgrounds, reworked concretion levels and condensed horizons in the Jurassic of western India: their significance for basin analysis. Journal of the Geological Society 149, 313-331.

Fürsich, F.T., Pandey, D.K., Callomon, J.H., Jaitly, A.K. \& Singh, I.B., 2001. Marker beds in the Jurassic of the Kachchh Basin, western India: their depositional environment and sequence-stratigraphic significance. Journal of Palaeontological Society of India 46, 173-198.

Ghaznavi, A.A., Alam, M.M. \& Ahmad, A.H.M., 2015. Tectono-sedimentary and climatic setup for Dhosa Sandstone Member (Chari Formation) of Ler dome, Kachchh, western India. The Palaeobotanist 64, 117-128.

Ghaznavi, A.A., Ahmad, A.H.M., Alam, M.M. \& Quasim, M.A., 2018a. Heavy mineral study of Dhosa Sandstone, Kachchh Basin, Western India: Implication for provenance and tectonic setting. Journal of Geosciences Research 3, 1-12.

Ghaznavi, A.A., Khan, I., Quasim, M.A. \& Ahmad, A.H.M., 2018b. Provenance, tectonic setting, source weathering and palaeoenvironmental implications of Middle-Upper Jurassic rocks of Lerdome, Kachchh, western India: Inferences from petrography and geochemistry. Chemie der Erde - Geochemistry 78, 356-371.

Ghaznavi, A.A., Alam, M.M., Khan, Z. \& Ahmad, A.H.M., 2018c. Diagenetic evolution vis-a-vis reservoir characteristics of Dhosa sandstones, Ler dome, Kachchh, western India. Arabian Journal of Geosciences 11, 387-405.

Ghosh, S.K. \& Chatterjee, B.K., 1994. Depositional mechanisms as revealed from grain-size measures of the palaeoproterozoic Kolhan siliciclastics, Keonjhar District, Orissa, India. Sedimentary Geology 89, 181-196.

Griffiths, J.C., 1967. Scientific methods in the analysis of sediments. McGraw-Hill, New York, 508 pp.

Hartmann, D., 2007. From reality to model: operationalism and the value chain of particle size analysis of natural sediments. Sedimentary Geology 202, 383-401.

Kanhaiya, S. \& Singh, B.P., 2014. Spatial variation of textural parameters in a small river: An example from Khurar River, Khajuraho, Chhaterpur District, Madhya Pradesh, India. Global Journal of Earth Science and Engineering 1, 34-42.

Kanhaiya, S., Singh, B.P. \& Srivastava, V.K., 2017. Surface textures of detrital quartz grains derived from Bundelkhand granite in the Khurar River, central India. Vietnam: Geo-spatial technology and Earth resources. Publishing House for Science and Technology, 575-581.

Khozyem, H., Adatte, T., Keller, G., Spangenberg, J.E., Saravanan, N. \& Bajpai, S., 2013. Paleoclimate and paleoenvironment of the Naredi Formation (Early Eocene), Kutch, Gujarat, India. Geological Society of India Special Publication 1, 165-182. 
Krinsley, D.H. \& Doornkamp, J.C., 1973. Atlas of Quartz Sand Surface Textures. Cambridge University Press, Cambridge, $91 \mathrm{pp}$.

Krumbein, W.C., 1934. Size frequency distribution of sediments. Journal of Sedimentary Research 4, 65-77.

Krumbein, W.C. \& Pettijohn, F.J., 1938. Manual of Sedimentary Petrography. Appleton Century, New York, 549 pp.

Longhitano, S.G., Chiarella, D. \& Muto, F. 2014. Three dimensional to two dimensional cross strata transition in the lower Pleistocene Catanzaro tidal strait transgressive succession (southern Italy). Sedimentology 61, 2136-2171.

Madhavaraju, J., García y Barragán, J.C., Hussain, S.M. \& Mohan, S.P., 2009. Microtextures on quartz grains in the beach sediments of Puerto Peñasco and Bahia Kino, Gulf of California, Sonora, Mexico. Revista Mexicana de Ciencias Geológicas 26, 367-379.

Mahaney, W.C., 1998. Scanning electron microscopy of Pleistocene sands from Yamal and TazPeninsu-las, Ob river esutary, northwestern Siberia. Quaternary International 45/46, 49-58.

Mahaney, W.C., 2002. Atlas of Sand Grain Surface Textures and Applications. Oxford University Press, New York. 237 pp.

Margolis, S.V. \& Krinsley, D.H., 1974. Processes of formation and environmental occurrence of microfeatures on detrital quartz grains. American Journal of Science 275, 449-464.

Maurya, D.M., Thakkar, M.G., Patidar, A.K., Bhandari, S., Goyal, B. \& Chamyal, L.S., 2008. Late Quaternary geomorphic evolution of the coastal zone of Kachchh, western India. Journal of Coastal Research 24, 746-758.

McBride, E.F., 1971. Mathematical treatment of size distribution data. [In:] R.E. Carver (Eds.): Procedures in Sedimentary Petrology. Wilson Interscience, 95-114 pp.

McCabe, P.J., 1977. Deep distributary channels and giant bedforms in the Upper Carboniferous of the Central Pennines, northern England. Sedimentology 24, 271-290.

Moiola, R.J. \& Weiser, D., 1968. Textural parameters: An evaluation. Journal of Sedimentary Research 38, 45-53.

Molinaroli, E., Guerzoni, S., De Falco, G., Sarretta, A., Cucco, A., Como, S., Simeone, S., Perilli, A. \& Magni, P., 2009. Relationships between hydrodynamic parameters and grain size in two contrasting transitional environments: the Lagoons of Venice and Cabras, Italy. Sedimentary Geology 219, 196-207.

Myrow, P.M. \& Hiscott, R.N., 1991. Shallow-water gravity-flow deposits, Chapel Island Formation, southeast Newfoundland, Canada. Sedimentology 38, 935-959.

Pandey, D.K., Alberti M. \& Fürsich, F.T., 2013. Ammonites from the Oxfordian (bifurcates zone) strata of Gangta Bet, Kachchh, Western India. Journal of the Palaeontological Society of India 58, 139-174.

Pandey, D.K., Fürsich, F.T. \& Sha, J., 2009. Interbasinal marker intervals - A case study from the Jurassic basins of Kachchh and Jaisalmer, western India. Science in China Series D: Earth Sciences 52, 1924.

Passega, R., 1957. Texture as a characteristic of clastic deposition. American Association of Petroleum Geologist 41, 1952-1984.
Passega, R., 1964. Grain size representation by C-M pattern as a geological tool. Journal of Sedimentary Research 34, 830-847.

Rai, J., Garg, S., Gupta, M., Singh, A., Pandey, D.K., Fürsich, F.T. \& Garg, R., 2015. Integrated biostratigraphy of the Jurassic strata of the Wagad uplift, Kachchh, Western India. Volumina Jurassica 13, 55-80.

Rajganapathi, V.C., Jitheshkumar, N., Sundararajan, M., Bhat, K.H. \& Velusamy, S., 2013. Grain size analysis and characterization of sedimentary environment along Thiruchendur coast, Tamilnadu, India. Arabian Journal of Geosciences 6, 4717-4728.

Rani, R., Shukla, U., Saha, O. \& Pandey, M., 2011. Lithofacies supported granulometric analysis of the Middle Siwalik Subgroup of Mohand area, North-Western Himalaya, India: A palaeoenvironmental application. Memoir of the Geological Society of India 77, 469-491.

Reading, H.G., 1996. Sedimentary Environments: Processes, Facies and Stratigraphy. 3rd Edition, Blackwell, Oxford, $689 \mathrm{pp}$.

Sahu, B.K., 1964. Depostional mechanisms from the size analysis of clastic sediments. Journal of Sedimentary Research 34, 73-83.

Sahu, B.K., 1983. Multi group discrimination of depositional environments using size distribution statistics. Indian Journal of Earth Science 10, 20-29.

Srivastava, A.K. \& Mankar, R.S., 2008. Grain size analysis and depositional pattern of upper Gondwana sediments (Early Cretaceous) of Salbardi area, districts Amravati, Maharashtra and Betul, Madhya Pradesh. Journal of Geological Society of India 73, 393-406.

Stewart, H.B., 1958. Sedimentary reflection on depositional environment, in San Miguel lagoon, Baju California, Mexico. American Association of Petroleum Geologist Bulletin 42, 2567-2618.

Sutherland, R.A. \& Lee, C.T., 1994. Discrimination between coastal sub environments using textural characteristics. Sedimentology 41, 1133-1145.

Talib, A. \& Gaur, K.N., 2008. Affinities and palaeobiogeographic implications of middle to late jurassic foraminifera from Jumara Hill, Kutch, India. Neues Jahrbuchfür Geologie und Paläontologie - Abhandlungen 247, 313-323.

Talib, A., Upadhyay, G. \& Haseen, M., 2014. Jurassic foraminifera from Jajiya Member, Jaisalmer Formation, Western Rajasthan. Journal of Geological Society of India $83,38-46$.

Tripathi, A. \& Hota, R.N., 2013. Granulometric Analysis of Ib River Sediments near Sundargarh, Odisha. Vistas in Geological Research. Utkal University Special Publication in Geology, pp. 74-79.

Visher, G.S., 1969. Grain size distribution and depositional process. Journal of Sedimentary Research 39,1074-1106.

Weltje, G.J. \& Prins, M.A., 2007. Genetically meaningful decomposition of grain-size distributions. Sedimentary Geology 202, 409-424.

Manuscript received: 14 July 2018 Revision accepted: 28 January 2019 